\title{
Peroxy radicals in the summer free troposphere: seasonality and potential for heterogeneous loss
}

\author{
A. E. Parker ${ }^{1, *}$, P. S. Monks ${ }^{1}$, K. P. Wyche ${ }^{1}$, J. M. Balzani-Lööv ${ }^{2}$, J. Staehelin ${ }^{2}$, S. Reimann ${ }^{3}$, G. Legreid ${ }^{3}$, \\ M. K. Vollmer ${ }^{3}$, and M. Steinbacher ${ }^{3}$ \\ ${ }^{1}$ Department of Chemistry, University of Leicester, Leicester, UK \\ ${ }^{2}$ Institute for Atmospheric and Climate Science, ETH, Zurich, Switzerland \\ ${ }^{3}$ EMPA, Dubendorf, Switzerland \\ * now at: PC2A, Université des Sciences et Technologies de Lille, Lille, France
}

Received: 27 June 2008 - Published in Atmos. Chem. Phys. Discuss.: 30 September 2008

Revised: 6 February 2009 - Accepted: 11 March 2009 - Published: 20 March 2009

\begin{abstract}
The sum of peroxy radicals $\left(\mathrm{HO}_{2}+\Sigma_{i} \mathrm{R}_{i} \mathrm{O}_{2}\right)$ and supporting trace gases were measured on the Jungfraujoch ( $3580 \mathrm{~m}$ a.s.l.) during the late summer of 2005 . The period was marked by extended times of heavy snow which led to reduction in the observed peroxy radicals during the snowy periods that was greater than the concomitant reduction in $j\left(\mathrm{O}^{1} \mathrm{D}\right)$. In the limit a first order loss rate of $0.0063 \mathrm{~s}^{-1}$ can be derived for the peroxy radical loss in the snowy conditions that could be potentially ascribed to a heterogenous loss process. On snow free days photolysis of HCHO is shown to be a significant peroxy radical source. The seasonal trends of the peroxy radical concentrations have been mapped from the winter to summer transition in line with previous experiments. Net ozone production in late summer at the Jungfraujoch was net neutral to marginally ozone destructive. A value of $28 \pm 4$ pptv is calculated for the ozone compensation point for the snow free days.
\end{abstract}

\section{Introduction}

Peroxy radicals $\left(\mathrm{HO}_{2}+\Sigma_{i} \mathrm{R}_{i} \mathrm{O}_{2}\right)$ are key intermediates and chain carriers in the photochemical cycling of ozone in the troposphere (e.g. Monks, 2005). Peroxy radicals are formed via the oxidation of anthropogenic and biogenic species in the atmosphere such as $\mathrm{CO}, \mathrm{CH}_{4}$ and other organic compounds. Ozone is produced via the peroxy radical catalysed oxidation of $\mathrm{NO}$ to $\mathrm{NO}_{2}$ and subsequent photolysis of $\mathrm{NO}_{2}$,

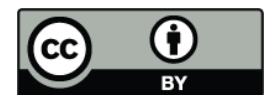

Correspondence to: P. S. Monks (p.s.monks@ leicester.ac.uk) whilst ozone can also be destroyed through reaction with $\mathrm{HO}_{2}$ (Monks, 2005). Owing to the short lifetime of peroxy radicals $\left(\mathrm{HO}_{2}\right.$ has a lifetime on the order of a minute in clean air, much less than a minute in polluted air (Monks, 2005)), they give a good indication in combination with NO of insitu photochemical ozone production and loss. In addition, the self- and cross-reactions of peroxy radicals to form peroxides (e.g. $\mathrm{H}_{2} \mathrm{O}_{2}$ ) are a major sink for $\mathrm{HO}_{2}$ and $\mathrm{OH}$ (Reeves and Penkett, 2003). The measurement of peroxy radicals thus remains of central importance in atmospheric chemistry, and rapid progress has been made in recent years with many deployments utilising various techniques for both ground and airborne studies (Cantrell et al., 2003; Edwards et al., 2003; Green et al., 2003, 2006; Heard and Pilling, 2003; Mihelcic et al., 2003; Mihele and Hastie, 2003; Salisbury et al., 2001; Sommariva et al., 2004).

The high altitude research station Jungfraujoch is situated on a saddle point located at $7^{\circ} 59^{\prime} 2^{\prime \prime} \mathrm{E}, 46^{\circ} 32^{\prime} 53^{\prime \prime} \mathrm{N}$ and $3580 \mathrm{~m}$ a.s.l. between two mountains, the Jungfrau to the north-west (4158 ma.s.l.) and the Mönch to the south-east (4099 ma.s.l.) in the Swiss Alps. The air pressure at the Sphinx laboratory ranges from 619 mbar to 675 mbar, with a mean pressure of $653.3 \mathrm{mbar}$, and air temperature ranges from $-37^{\circ} \mathrm{C}$ to $+10^{\circ} \mathrm{C}$, with a mean temperature of $-8.2^{\circ} \mathrm{C}$. In winter and very often in spring and autumn the Jungfraujoch is located in the free troposphere (Lugauer et al., 1998; Zanis et al., 2007, 2000a). As the Jungfraujoch is situated on a mountain saddle point, it experiences air from essentially two directions, north-west and south-east. To the north-west air arrives at the Jungfraujoch from the Swiss Plateau and Northwestern Europe, whilst from the south-east it arrives from the direction of Italy and the Po Valley.

Published by Copernicus Publications on behalf of the European Geosciences Union. 
Table 1. Photolysis rates measured along with reference for quantum yield and absorption cross-section reference.

\begin{tabular}{|c|c|c|}
\hline Photolysis rate & Quantum yield, $\phi$ & Absorption cross-section, $\sigma$ \\
\hline$j\left(\mathrm{O}^{1} \mathrm{D}\right)$ & Matsumi et al. (2002) & Malicet et al. (1995) \\
\hline$j\left(\mathrm{NO}_{2}\right)$ & Troe (2000) & Coquart et al. (1995) \\
\hline$j(\mathrm{HCHO})$ & Atkinson et al (1999) & Meller and Moortgat (2000) \\
\hline$j\left(\mathrm{H}_{2} \mathrm{O}_{2}\right)$ & Unity & Atkinson et al. (1999) \\
\hline$j(\mathrm{HONO})$ & Unity & Bongartz et al. (1991) \\
\hline$j\left(\mathrm{CH}_{3} \mathrm{COOH}\right)$ & Unity & Atkinson et al. (1999) \\
\hline$j\left(\mathrm{CH}_{3} \mathrm{CHO}\right)$ & Atkinson et al. (1999) & Atkinson et al. (1999) \\
\hline$j\left(\mathrm{CH}_{3} \mathrm{COCH}_{3}\right)$ & Gierczak et al. (1998) & Gierczak et al. (1998) \\
\hline$j(\mathrm{PAN})$ & Unity & Talukdar et al. (1995) \\
\hline$j\left(\mathrm{HNO}_{3}\right)$ & Unity & Atkinson et al. (2004) \\
\hline$j\left(\mathrm{NO}_{3}\right)$ & Unity & Yokelson et al. (1994) \\
\hline$j\left(\mathrm{I}_{2}\right)$ & Unity & Saiz-Lopez et al. (2004) \\
\hline
\end{tabular}

Although the site at the Jungfraujoch is sometimes influenced by boundary layer air masses (Lugauer et al., 1998; Reimann et al., 2004; Zanis et al., 2003; Zellweger et al., 2000), it is ideal for the study of the European free troposphere. The free troposphere (FT) is the region of the atmosphere located between the planetary boundary layer and the tropopause. The colder temperatures and lack of deposition in the free troposphere compared to the boundary layer lead to longer chemical lifetimes for many species (e.g. ozone) in the free troposphere compared to the boundary layer. As much of the transport of chemical species within the atmosphere takes place in the free troposphere, the combination of long-range transport and longer chemical lifetimes mean that the chemistry of the free troposphere is of fundamental importance in determining the chemical composition of regions remote from pollutant source regions (Europe, 2008).

This paper describes a series of peroxy radical and supporting measurements made at the Jungfraujoch during the summer of 2005 . The measurements compliment a series of similar measurements made that have mapped the transition from winter-time to spring-time photochemistry at the Jungfraujoch (Zanis et al., 1999, 2003, 2000a, b). The measurements are explored in term of the production and loss processes of the peroxy radicals and the concomitant production or loss of ozone in the seasonal context. The summertime 2005 campaign was marked by periods of significant snow-fall, the effect of which on the radical chemistry is also explored.

\section{Measurement details}

\subsection{The PERCA instrument}

The Chemical Amplification technique was introduced by Cantrell in the early 1980s (Cantrell and Stedman, 1982, 1984) and has been widely deployed since then (Cantrell et al., 1993; Fleming et al., 2006a, b; Green et al., 2003, 2006;
Mihele and Hastie, 2003; Monks et al., 1998; Zanis et al., 2000a). In brief, the PERCA technique utilises the radical catalysed conversion of $\mathrm{NO}$ and $\mathrm{CO}$ into $\mathrm{NO}_{2}$ and $\mathrm{CO}_{2}$ respectively via addition of $\mathrm{NO}(3 \mathrm{ppmv})$ and $\mathrm{CO}(6 \% \mathrm{v} / \mathrm{v})$ to the inlet region. $\mathrm{NO}_{2}$ is subsequently detected via aqueous luminol (5-amino-2,3-dihydro-1,4-pthalazinedione) solution chemiluminescence at $\lambda=424 \mathrm{~nm}$ with an improved LMA-3 detector as described by Green et al. (2006).

$$
\begin{aligned}
& \mathrm{RO}_{2}+\mathrm{NO} \rightarrow \mathrm{RO}+\mathrm{NO}_{2} \\
& \mathrm{RO}+\mathrm{O}_{2} \rightarrow \mathrm{R}^{\prime} \mathrm{CHO}+\mathrm{HO}_{2} \\
& \mathrm{HO}_{2}+\mathrm{NO} \rightarrow \mathrm{OH}+\mathrm{NO}_{2} \\
& \mathrm{OH}+\mathrm{CO} \rightarrow \mathrm{H}+\mathrm{CO}_{2}
\end{aligned}
$$

$\mathrm{H}+\mathrm{O}_{2}+\mathrm{M} \rightarrow \mathrm{HO}_{2}+\mathrm{M}$

$$
\mathrm{CO}+\mathrm{NO}+\mathrm{O}_{2} \rightarrow \mathrm{CO}_{2}+\mathrm{NO}_{2}
$$

The yield of $\mathrm{NO}_{2}$ is equal to $\mathrm{CL} \times\left[\mathrm{HO}_{2}+\Sigma_{i} \mathrm{R}_{i} \mathrm{O}_{2}+\Sigma_{i} \mathrm{R}_{i} \mathrm{O}+\mathrm{OH}\right]$, where $\mathrm{CL}$ is the chain length, i.e. the number of $\mathrm{HO}_{2} / \mathrm{OH}$ conversion cycles that occur before termination.

A significant background $\mathrm{NO}_{2}$ signal is also observed from other sources such as the reaction of ozone with the reagent NO. Assuming a chain length of 100 (i.e. each radical molecule produces 100 molecules of $\mathrm{NO}_{2}$ ) and a radical concentration of $20 \mathrm{pptv}$, the radical chain cycle would produce 2 ppbv of $\mathrm{NO}_{2}$. Under polluted conditions, ambient ozone could contribute up to $100 \mathrm{ppbv}$ of $\mathrm{NO}_{2}$. Consequently, it is necessary to periodically measure only the background $\mathrm{NO}_{2}$ produced by means other than peroxy radical conversion. This is achieved by injecting $\mathrm{CO}$ downstream of the NO injection point. OH produced as a result of Reaction (R3) cannot be recycled into $\mathrm{HO}_{2}$ as Reaction (R4) and Reaction (R5) do not take place, and instead some $\mathrm{OH}$ reacts with NO in a chain termination step (Reaction R7), whilst remaining radicals are lost to the walls of the inlet.

$$
\mathrm{OH}+\mathrm{NO}+\mathrm{M} \rightarrow \mathrm{HONO}+\mathrm{M}
$$

A flow of inert gas (nitrogen) is added in place of the $\mathrm{CO}$ so that in amplification mode $\mathrm{NO}$ and $\mathrm{CO}$ are injected upstream of $\mathrm{N}_{2}$, and in background mode $\mathrm{NO}$ and $\mathrm{N}_{2}$ are injected upstream of $\mathrm{CO}$. This ensures that the properties of the sample gas flow remain unchanged in both operation modes. It also helps to reduce pressure pulsing in the detected signal and allows the flows to settle again more quickly after switching. The LMA-3 detectors are calibrated daily by the addition of known concentrations of $\mathrm{NO}_{2}$ and the chain length is calibrated every 4 to 5 days by addition of known concentrations of $\mathrm{CH}_{3} \mathrm{O}_{2}$. For details see Green et al. (2006) and Clemitshaw et al. (1997). The sensitivity of the PERCA instrument 
to humidity is well known (Mihele and Hastie, 1998; Mihele et al., 1999) and consequently a water correction as per Salisbury et al. (2002) has been applied to all data in this work. This correction is relatively small out of the boundary layer as humidity is generally low.

The uncertainty in the PERCA measurements leads to a calculated accuracy of about $35 \%$. The sources of error and estimated magnitude of error are as follows: Radical calibration $\left(j\left(\mathrm{CH}_{3} \mathrm{I}\right)\right.$ measurement $(15 \%)$, mass flow controller calibration (zero air and $\left.\mathrm{CH}_{3} \mathrm{I}\right)(5 \%), \mathrm{CH}_{3} \mathrm{I}$ permeation tube leak (5\%), volume of photolysis cell (5\%)), $\mathrm{NO}_{2}$ detection (background variability (10\%), thermal instability of luminol $(20 \%)$ and the water correction factor error $(20 \%))$. This gives an uncertainty value of $18 \%$ for radical calibration and $22.4 \%$ for $\mathrm{NO}_{2}$ calibration. Therefore, the overall radical measurement uncertainty is $35 \%$.

\subsection{Photolysis frequency measurements}

A range of photolysis frequencies were measured during this work with a fast, monolithic single-monochromator spectral radiometer with a temperature-stabilized diode array detector. The spectral radiometer is a commercial instrument available from Meterologie Consult $\mathrm{GmbH}$, Germany. A full description of the spectral radiometer deployed during these measurements, including characterisation and calibration details is given in (Edwards and Monks, 2003). A range of photolysis frequencies were derived from the actinic flux measured with the spectral radiometer as shown in Table 1 along with the reference used for quantum yield and absorption cross-section data.

\subsection{Other measurements}

Many additional measurements were carried out during this work and are summarized in Table 2. Ozone was measured with a commercially available Thermo Environmental Instruments 49c UV absorption instrument, whilst $\mathrm{CO}$ was measured with another commercial instrument, a HORIBA APMA-360 which utilises the nondispersive infrared (NDIR) technique. $\mathrm{NO}, \mathrm{NO}_{\mathrm{x}}$ and $\mathrm{NO}_{\mathrm{y}}$ were all measured with a commercially available Ecophysics CraNOx instrument equipped with two temperature controlled CLD 770 AL pptv chemiluminescence detectors. $\mathrm{NO}_{\mathrm{x}}$ was measured by conversion to $\mathrm{NO}$ on a PLC 760 photolytic convertor, whilst $\mathrm{NO}_{\mathrm{y}}$ was converted on a gold catalyst heated to $300^{\circ} \mathrm{C}$ with the addition of 2\% CO (Messer-Griesheim $\mathrm{GmbH}, 99.997 \%$ ) to act as a reducing agent. $\mathrm{NO}_{2}$ was then reported by subtraction of NO from $\mathrm{NO}_{\mathrm{x}}$ (Zellweger et al., 2000). These observations run continuously as part of the Swiss National Air Pollution Monitoring Network (NABEL).

Peroxy acetyl nitrate (PAN) was measured with a commercially available Meterologie Consult $\mathrm{GmbH}$ gas chromatograph (GC) with electron capture detection (ECD) and calibration unit. The technique is described in Schmidt et
Table 2. Species measured at the Jungfraujoch during the measurement period.

\begin{tabular}{lll}
\hline Species measured & Technique & Institute \\
\hline $\mathrm{O}_{3}$ & UV absorption & EMPA \\
$\mathrm{CO}$ & NDIR & EMPA \\
$\mathrm{NO}$ & Chemiluminescence $\left(\mathrm{O}_{3}\right.$ reaction $)$ & EMPA \\
$\mathrm{NO}_{2}$ & Calculated from $\mathrm{NO}_{\mathrm{x}}-\mathrm{NO}$ & EMPA \\
$\mathrm{NO}_{\mathrm{x}}$ & Photolytic conversion & EMPA \\
$\mathrm{NO}_{\mathrm{y}}$ & Au catalytic conversion & EMPA \\
$\mathrm{PAN}$ & GC-ECD & ETHZ \\
$\mathrm{HCHO}$ & Hantzsch fluorescence & ETHZ \\
$\mathrm{CH}$ & GC-FID & EMPA \\
VOCs & GC-MS & EMPA \\
OVOCs & GC-MS & EMPA \\
\hline
\end{tabular}

al. (1998), and the instrument deployed at the Jungfraujoch during 2005 is described in Balzani Lööv et al. (2007).

Formaldehyde was measured using an instrument based on the Hantzsch fluorescence technique similar to the AERO LASER $\mathrm{CH}_{2} \mathrm{O}$ analyser AL4021. The Hantzsch technique is a liquid phase technique, and as such requires the $\mathrm{HCHO}$ to be analysed to be transferred from the gas to liquid phase. Once in the liquid phase the $\mathrm{HCHO}$ is reacted with 2,4-pentadione and $\mathrm{NH}_{3}$ to produce 3,5-diacetyl-1,4dihydrolutidine (DDL). DDL fluoresces at $510 \mathrm{~nm}$ if excited at $412 \mathrm{~nm}$ and thus can be measured. The Hantzsch technique is described in Kelly and Fortune (1994), and the instrument deployed at the Jungfraujoch during 2005 is described in Balzani Lööv et al. (2007).

Methane was measured via GC-FID and NMHCs (npentane, iso-pentane, $n$-hexane, benzene, toluene, trimethylbenzene, n-butane, isobutane, butadiene, ethylbenzene, isoprene, o-xylene and m-, p-xylene) were measured with an Agilent 5973N GC-MS with a pre-concentration system after Simmonds et al. (1995). The system is described in detail by Reimann et al. (2004).

There were also measurements of OVOCs (methanol, ethanol, propanol, butanol, 2-methyl-3-buten-2-ol (MBO), propanal, isopropanal, butanal, pentanal, hexanal, acetaldehyde, benzaldehyde, acrolein, methylacetate, ethylacetate, butylacetate, methyl vinyl ketone (MVK), methyl ethyl ketone(MEK), methacrolein, acetone and methyl tertiary butyl ether (MTBE)) made at the Jungfraujoch with a GC-MS system. The instrument was based on an Agilent HP 6890HP 5973N and constructed by EMPA (Legreid et al., 2007, 2008). In addition relative humidity, temperature, pressure, wind speed and wind direction were measured by the Swiss Meteorological Service. 
Table 3. Days of campaign considered "snowy" and "snow free".

\begin{tabular}{cc}
\hline Snow free & Snowy \\
\hline 30 Aug 2005-5 Sep 2005 inclusive & 6 Sep 2005-13 Sep 2005 inclusive \\
14 Sep 2005-16 Sep 2005 inclusive & 17 Sep 2005-18 Sep 2005 inclusive \\
\hline
\end{tabular}

\section{Results}

\subsection{Radicals and tracers observations}

The campaign time series of peroxy radicals, $\mathrm{O}_{3}, \mathrm{CO}, \mathrm{NO}$, $\mathrm{NO}_{2}$ and $j\left(\mathrm{O}^{1} \mathrm{D}\right)$ are shown in Fig. 1. It can be seen that peroxy radicals in the period 6 September 2005-12 September 2005 inclusive in addition to some days after this period are suppressed relative to the period up to and including 5 September 2005. The suppression of peroxy radicals corresponds to days on which there was heavy snowfall. In order to quantify the effect of snowfall, a metric was devised by which days with mean relative humidity over $76 \%$ were considered "snowy", whilst those with a mean relative humidity under $76 \%$ were considered "snow free". Table 3 shows which days were assigned to which category.

The data in Fig. 2a illustrates that during snow fall peroxy radical concentrations were much lower. The mean peak radical value is approximately 3 times greater on clear days than when it was snowing. It would be expected that $j\left(\mathrm{O}^{1} \mathrm{D}\right)$ is also reduced on the snowy days owing to attenuation of light by snow. However $j\left(\mathrm{O}^{1} \mathrm{D}\right)$ is not reduced to the same extent as the peroxy radicals. The mean diurnal cycles for $j\left(\mathrm{O}^{1} \mathrm{D}\right)$ for "snow free" and "snowy" days are shown in Fig. $2 b$.

The mean diurnal cycle for "snow free" days divided by the mean diurnal cycle for "snowy" days for the sum of peroxy radicals, $j\left(\mathrm{O}^{1} \mathrm{D}\right)$, ozone and carbon monoxide are shown in Fig. 3a. In contrast to peroxy radicals and $j\left(\mathrm{O}^{1} \mathrm{D}\right)$, the relative concentrations of ozone and carbon monoxide are very similar on both "snow free" and "snowy" days.

The same is not true however for some other trace species such as $\mathrm{NO}, \mathrm{NO}_{2}, \mathrm{HCHO}$ and PAN. Figure $3 \mathrm{~b}$ shows the mean diurnal cycle for "snow free" days divided by the mean diurnal cycle for "snowy" days for $\mathrm{NO}, \mathrm{NO}_{2}, \mathrm{HCHO}$ and PAN. It can be seen that these species (and especially the $\mathrm{NO}_{\mathrm{x}}$ ) are enhanced on the "snowy" days compared to the "snow free" days.

Owing to the topography at the Jungfraujoch, air approaches from essentially two directions only, the north west (towards Kleine Scheidegg and the Swiss plateau) and south east (down the glacier towards Italy).

On those days classified as "snowy", the air was mostly from the south east and on "snow free" days the air was predominantly from the northwest. There is clearly then a fundamental chemical difference in air masses depending on origin, with air from the south east arriving predominantly on "snowy" days and showing suppressed peroxy radicals and enhanced $\mathrm{NO}_{\mathrm{x}}$ compared to "snow free" days which are characterised by air of north west origin. The suppression of peroxy radicals is not however solely because of the enhanced $\mathrm{NO}_{\mathrm{x}}$, as shall be seen later.

Back trajectories have been run using a method adapted for use in the complex topography of the Swiss Alps (Legreid et al., 2008), and have been used to investigate air mass origins for the two periods of interest, "snow free" and "snowy". The trajectories show that for days classified as "snow free", the air masses arriving at the Jungfraujoch, although from various regions, are from north of the alps and principally the Swiss plateau and mainly of free tropospheric origin. However, on the days classified as "snowy" the air masses are mainly from the boundary layer in the south over northern Italy and the heavily polluted Po Valley. Examples of these back trajectories are shown in Fig. 4.

The Po Valley is the river basin of the Po River in northern Italy that flows from Monviso in the Alps to the Adriatic Sea south of Venice. The Po Valley is the major industrial centre of north Italy, with major cities situated within it including Turin, Milan, Padua, Brescia and Verona. The Po Valley is a hotspot for pollution (Martilli et al., 2002; Neftel et al., 2002; Silibello et al., 1998), with anthropogenic pollution levels that are amongst the highest in Europe (Dommen et al., 2002; Thielmann et al., 2002); previous measurement campaigns found up to $185 \mathrm{ppbV}$ of ozone in the foothills of the Alps north of Milan (Prévôt et al., 1997).

\subsection{Peroxy radical production and loss}

The suppression of peroxy radicals in southerly air could be due to two effects - less production or greater loss. Reduced $j\left(\mathrm{O}^{1} \mathrm{D}\right)$ on "snowy" days owing to the reduced visibility caused by the snow would lead to reduced production, however this may be counteracted by the generally more humid air encountered on these days. Enhanced $\mathrm{NO}_{\mathrm{x}}$ in the southerly air would lead to increased peroxy radical loss from the increase in reaction of peroxy radicals with $\mathrm{NO}_{\mathrm{x}}$. The industrialised Po Valley could be the source of this extra $\mathrm{NO}_{\mathrm{x}}$, and there is also the possibility of $\mathrm{NO}_{\mathrm{x}}$ production from lightning as the moist air from the Mediterranean region rises rapidly as it reaches the Alps, leading to lightning. There could also be another unknown peroxy radical sink other than self-reaction or reaction with $\mathrm{NO}_{\mathrm{x}}$ causing the reduction in peroxy radicals. 


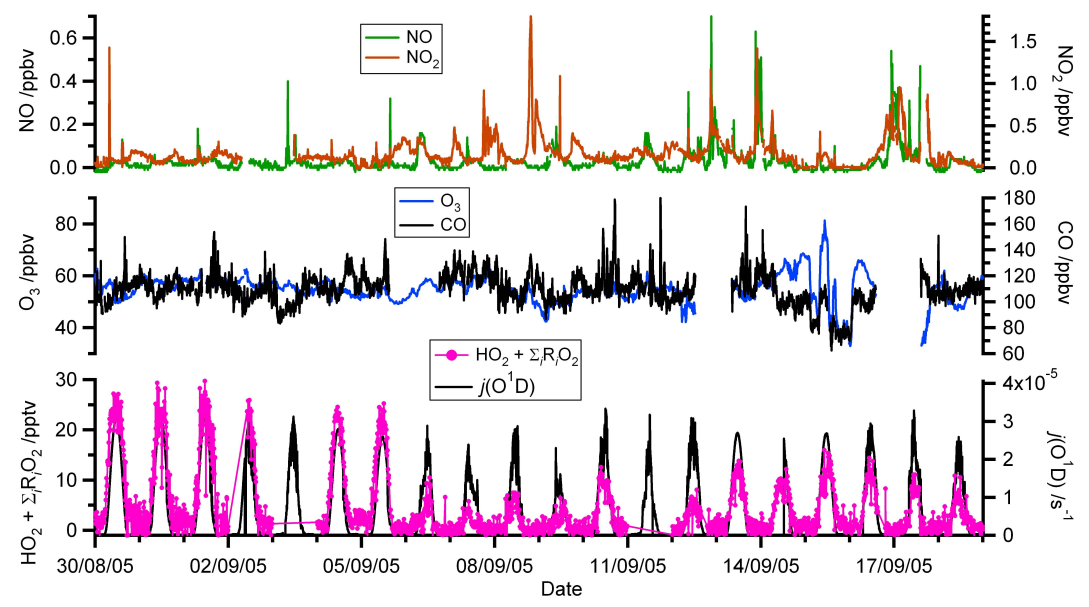

Fig. 1. Time series of peroxy radicals, $\mathrm{O}_{3}, \mathrm{CO}, \mathrm{NO}, \mathrm{NO}_{2}$ and $j\left(\mathrm{O}^{1} \mathrm{D}\right)$ measured at the Jungfraufoch from 30 August 2005-18 September 2005 inclusive.
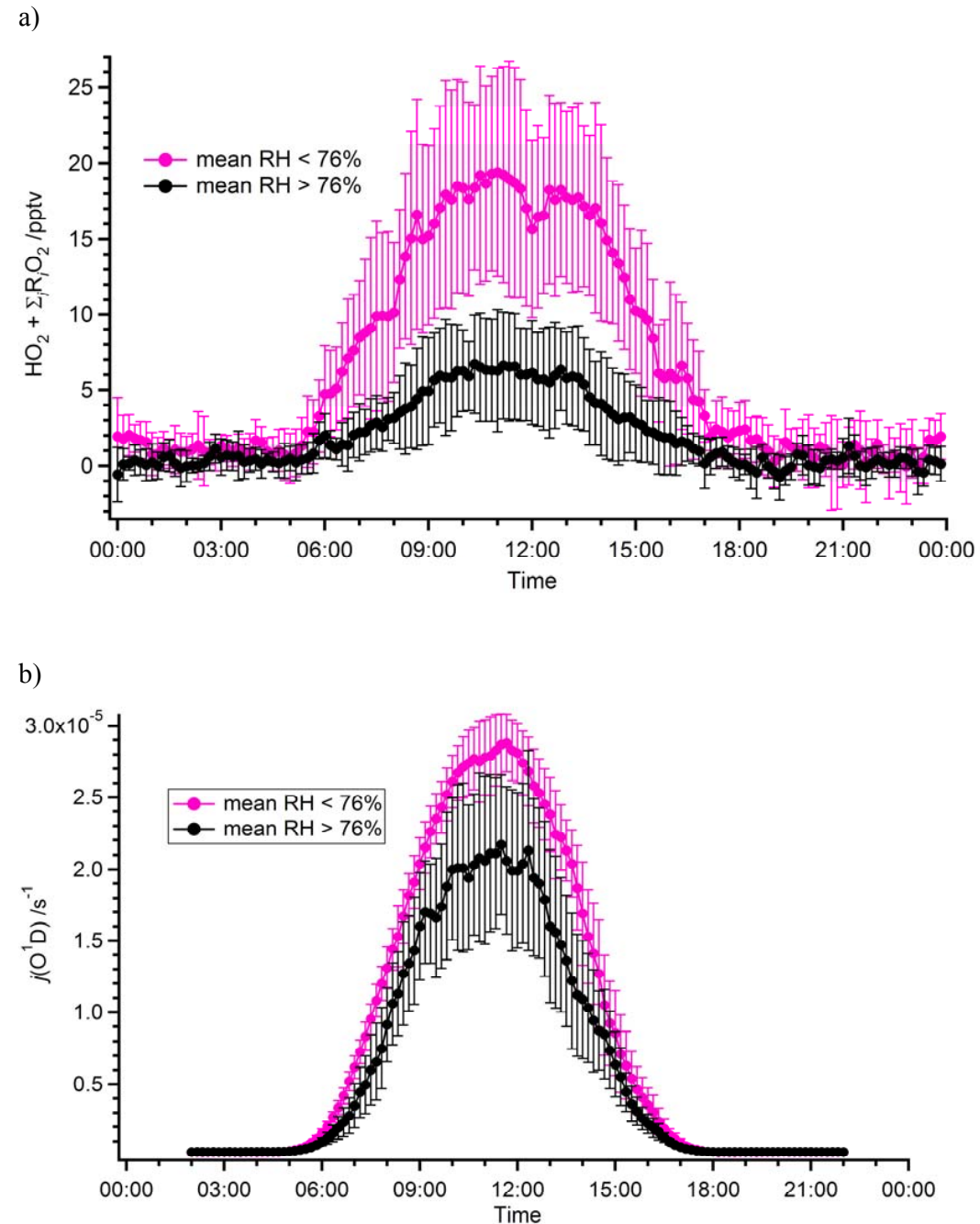

Fig. 2. (a) Mean peroxy radical mixing ratio and (b) mean $j\left(\mathrm{O}^{1} \mathrm{D}\right)$ diurnal cycle with days assigned as "snowy" or "snow free". Error bars are the standard deviation of the mean values. 
a)

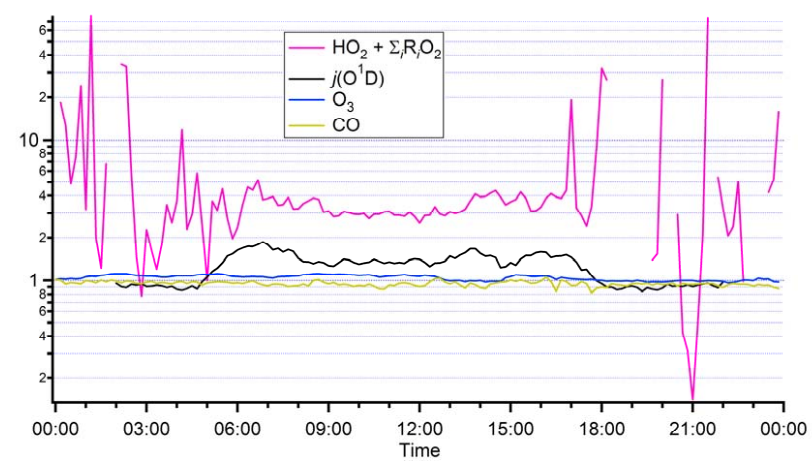

b)

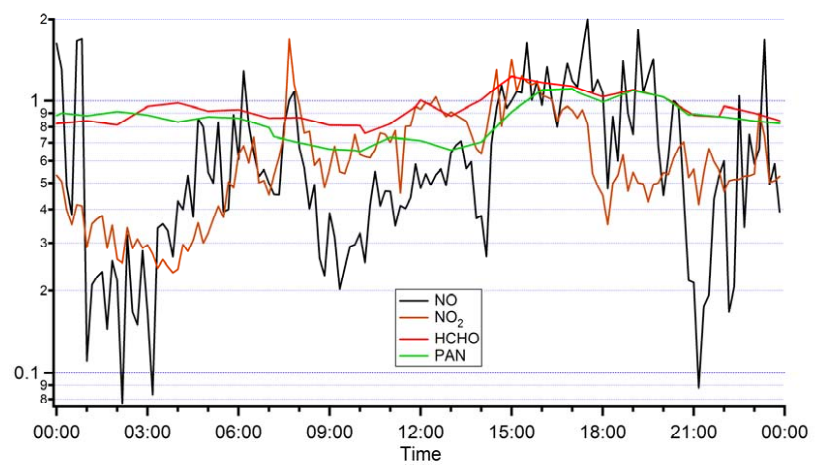

Fig. 3. (a) Mean diurnal cycle for "snow free" days divided by mean diurnal cycle for "snowy" days for peroxy radicals, $j\left(\mathrm{O}^{1} \mathrm{D}\right)$, ozone and $\mathrm{CO}$; (b) Mean diurnal cycle for "snow free" days divided by mean diurnal cycle for "snowy" days for $\mathrm{NO}, \mathrm{NO}_{2}, \mathrm{HCHO}$ and PAN.

In order to further elucidate the reasons for the suppressed peroxy radicals in the "snowy" air, a steady state analysis of the production and loss of peroxy radicals during this campaign has been carried out using the method described by Mihele and Hastie (2003). In steady state it can be shown that

$$
\begin{aligned}
{\left[\mathrm{HO}_{2}+\Sigma_{i} \mathrm{R}_{i} \mathrm{O}_{2}\right] } & \approx \sqrt{\frac{2 f \cdot j\left(\mathrm{O}^{1} D\right)\left[\mathrm{O}_{3}\right](1+\gamma)}{2 \cdot k_{\text {self }} \alpha(1+\beta)}} \\
& =\sqrt{\frac{f \cdot j\left(\mathrm{O}^{1} D\right)\left[\mathrm{O}_{3}\right]}{k_{\text {self }}}} \sqrt{\frac{1}{\alpha}} \sqrt{\frac{1}{1+\beta}} \sqrt{1+\gamma}
\end{aligned}
$$

Where $\alpha$ describes the partitioning between $\mathrm{HO}_{2}$ and $\mathrm{RO}_{2}$, thus:

$\alpha=\frac{\left[\mathrm{HO}_{2}\right]}{\left[\mathrm{HO}_{2}+\Sigma_{i} R_{i} \mathrm{O}_{2}\right]}$

$\beta$ is a measure of the dominant loss process for peroxy radicals, $\gamma$ is a measure of additional peroxy radical production from sources other than ozone photolysis and $k_{\text {self }}$ is a composite rate constant for the peroxy radical loss process via self-reaction. $\beta=L_{\mathrm{NO}_{\mathrm{x}}} / L_{\mathrm{SR}}$ and therefore if $\beta$ is less than one, then the dominant loss process is radical self-reaction rather than loss through reaction with $\mathrm{NO}_{\mathrm{x}}$. A $\gamma$ of zero indicates no excess production, whilst a $\gamma$ of less than zero indicates that a higher concentration of peroxy radicals is calculated from ozone photolysis than is actually observed (Mihele and Hastie, 2003).

A time series for $\beta$ is shown in Fig. 5a. It can be seen that $\beta$ is almost exclusively greater than 1 , indicating that loss of peroxy radicals is virtually always dominated by reaction with $\mathrm{NO}_{\mathrm{x}}$ rather than peroxy radical self-reactions. As the rate of reaction of $\left[\mathrm{HO}_{2}+\Sigma_{i} \mathrm{R}_{i} \mathrm{O}_{2}\right]+\mathrm{NO}$ is of a similar order to the rate of peroxy radical self reaction, only relatively low concentrations of $\mathrm{NO}_{\mathrm{x}}$ are required for the loss of peroxy radicals through reaction with $\mathrm{NO}_{\mathrm{x}}$ to become important or even dominate. For a diurnally averaged time series, the mixing ratio of $\mathrm{NO}$ is greater than that of peroxy radicals by a minimum of 2-3 times midway through the day, and more at other times. The value of $\beta$ reflects the suppression of peroxy radicals and enhancement of $\mathrm{NO}_{\mathrm{x}}$ on "snowy" compared to "snow free" days, with median $\beta$ four times larger on "snowy" days.

As mentioned, $\gamma$ is a measure of additional peroxy radical production from sources other than ozone photolysis. Figure $5 \mathrm{~b}$ is a plot of $\gamma$, from which it can be seen that on days designated "snowy" there is a marked decrease in $\gamma$ compared to days designated "snow free".

The median $\gamma$ for "snow free" days is $\gamma=0.19$, indicating that whilst the majority of peroxy radical production is from the photolysis of ozone to produce $\mathrm{O}\left({ }^{1} \mathrm{D}\right)$ and then subsequent reaction with water vapour to produce $\mathrm{OH}$, followed by $\mathrm{OH}$ initiated oxidation of $\mathrm{CO}, \mathrm{CH}_{4}$ and other organic compounds, there is an appreciable level of peroxy radical production from other sources.

However, for "snowy" days the median $\gamma$ value is $\gamma=-0.49$, indicating that either there is an overestimation of peroxy radical production or an underestimation of peroxy radical losses. As production via ozone photolysis is likely to be fairly well constrained (as $j\left(\mathrm{O}^{1} \mathrm{D}\right)$ and water vapour were both measured) and any additional production terms would lead to $\gamma$ being even more negative, it is likely that there is an underestimation of peroxy radical losses.

The radical loss term can be written as:

$L\left[\mathrm{HO}_{2}+\Sigma_{i} \mathrm{R}_{i} \mathrm{O}_{2}\right]=2 . k_{\text {self }} \cdot \alpha(1+\beta)\left[\mathrm{HO}_{2}+\Sigma_{i} \mathrm{R}_{i} \mathrm{O}_{2}\right]^{2}$

where the loss from self-reaction is from the following reactions:

$\mathrm{HO}_{2}+\mathrm{HO}_{2} \rightarrow \mathrm{H}_{2} \mathrm{O}_{2}+\mathrm{O}_{2}$

$\mathrm{HO}_{2}+\mathrm{RO}_{2} \rightarrow \mathrm{ROOH}+\mathrm{O}_{2}$

$\mathrm{RO}_{2}+\mathrm{RO}_{2} \rightarrow \mathrm{ROOR}+\mathrm{O}_{2}$ 

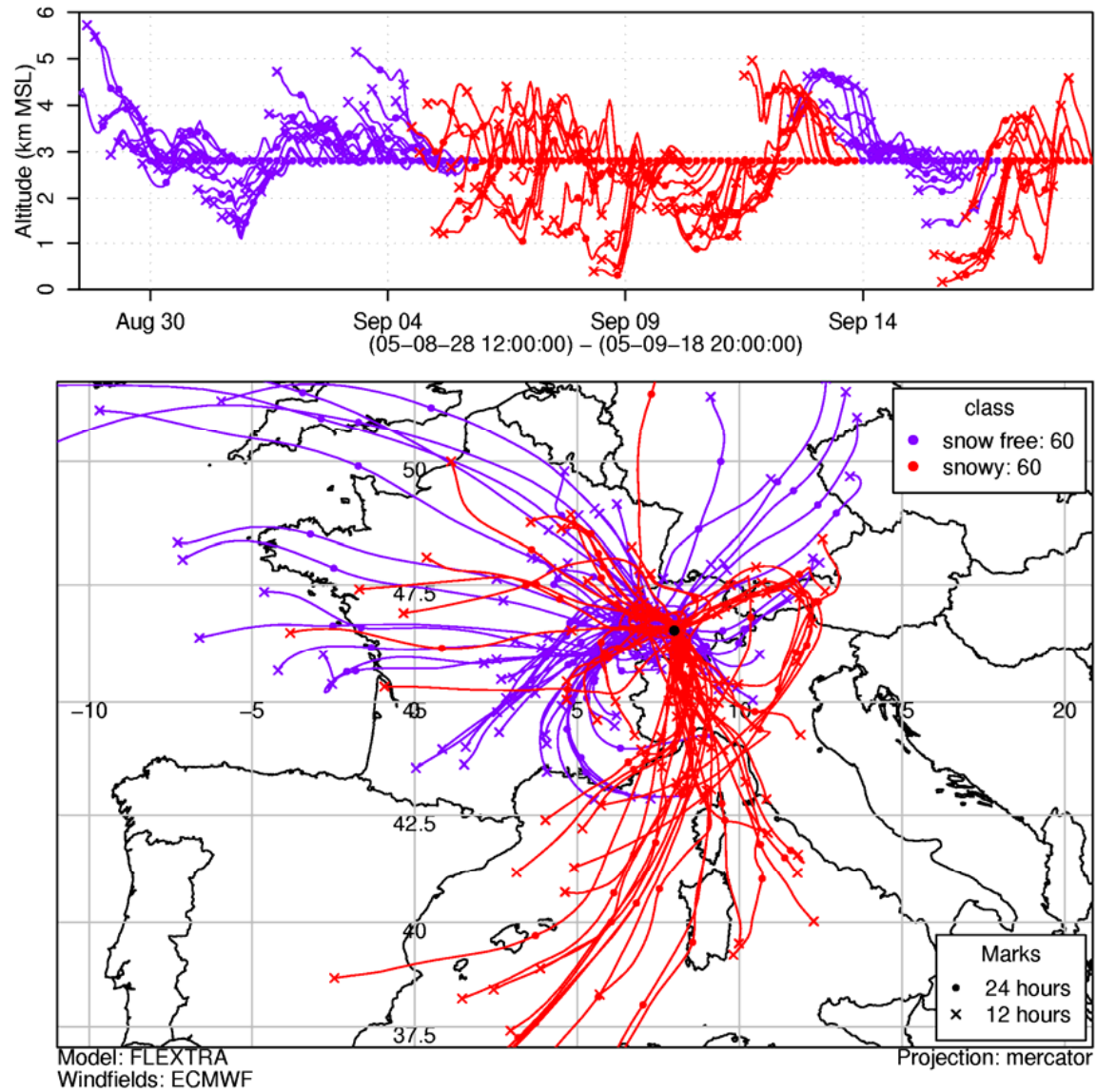

Fig. 4. Back trajectories for air masses arriving at Jungfraujoch on days classified as "snowy" and "snow free" calculated using a method adapted for use in the complex topography of the Swiss Alps.

which leads to the following self-reaction loss rate,

$L_{S R}=2 k_{8}\left[\mathrm{HO}_{2}\right]\left[\mathrm{HO}_{2}\right]+2 k_{9}\left[\mathrm{HO}_{2}\right]\left[\mathrm{RO}_{2}\right]+2 k_{10}\left[\mathrm{RO}_{2}\right]\left[\mathrm{RO}_{2}\right]$

Assuming that $k_{8} \approx k_{9}$, and that $k_{10}$ is slow enough that Reaction (R10) can be discarded, Eq. (4) reduces to that found in Mihele and Hastie (2003):

$L_{S R}=2 . k_{\text {self }} \cdot \alpha \cdot\left[\mathrm{HO}_{2}+\Sigma_{i} \mathrm{R}_{i} \mathrm{O}_{2}\right]^{2}$

However, the assumption in the derivation of the selfreaction loss rate that $k_{8} \approx k_{9}$ only holds if $\mathrm{RO}_{2}$ is solely in the form of $\mathrm{CH}_{3} \mathrm{O}_{2}$, neglecting the contribution of other species. If the acetylperoxy radical $\left(\mathrm{CH}_{3} \mathrm{C}(\mathrm{O}) \mathrm{O}_{2}\right)$ is introduced as a generic fast reacting peroxy radical to test the effect of additional $\mathrm{RO}_{2}$ species in the form of the ratio of $\delta=\left[\mathrm{CH}_{3} \mathrm{C}(\mathrm{O}) \mathrm{O}_{2}\right] /\left(\left[\mathrm{CH}_{3} \mathrm{O}_{2}\right]+\left[\mathrm{CH}_{3} \mathrm{C}(\mathrm{O}) \mathrm{O}_{2}\right]\right)$, then the self-reaction loss rate reduces thus:

$L_{S R}=2 .\left(k_{8} \alpha^{2}+k_{11} \alpha(1-\alpha)(1-\delta)+k_{12}(1-\alpha)^{2}(1-\delta)^{2}+\right.$

$\left.k_{13} \alpha(1-\alpha) \delta+k_{14}(1-\alpha)^{2} \delta(1-\delta)+k_{15}(1-\alpha)^{2} \delta^{2}\right)$

$\left[\mathrm{HO}_{2}+\Sigma_{i} \mathrm{R}_{i} \mathrm{O}_{2}\right]^{2}$ where

$\mathrm{HO}_{2}+\mathrm{CH}_{3} \mathrm{O}_{2} \rightarrow$ products

$\mathrm{CH}_{3} \mathrm{O}_{2}+\mathrm{CH}_{3} \mathrm{O}_{2} \rightarrow$ products

$\mathrm{HO}_{2}+\mathrm{CH}_{3} \mathrm{C}(\mathrm{O}) \mathrm{O}_{2} \rightarrow$ products

$\mathrm{CH}_{3} \mathrm{O}_{2}+\mathrm{CH}_{3} \mathrm{C}(\mathrm{O}) \mathrm{O}_{2} \rightarrow$ products

$\mathrm{CH}_{3} \mathrm{C}(\mathrm{O}) \mathrm{O}_{2}+\mathrm{CH}_{3} \mathrm{C}(\mathrm{O}) \mathrm{O}_{2} \rightarrow$ products

If $\delta$ is set to 0.5 , that is half of the $\mathrm{RO}_{2}$ present is in the form of acetylperoxy (the remaining half being $\mathrm{CH}_{3} \mathrm{O}_{2}$ ), then at $298 \mathrm{~K}$, the combined peroxy radical self-reaction rate is approximately double the self-reaction rate when $\delta$ is zero. Further to this, the rate constant for the reaction of acetylperoxy with NO is approximately 2.6 times faster than that for methylperoxy $\left(\mathrm{CH}_{3} \mathrm{O}_{2}\right)$ with $\mathrm{NO}$ at $298 \mathrm{~K}$. Consequently, the loss rate of peroxy radicals through reaction with $\mathrm{NO}_{\mathrm{x}}$ will also be greater than if all the $\mathrm{RO}_{2}$ were $\mathrm{CH}_{3} \mathrm{O}_{2}$. 
Table 4. Mean daily maximum peroxy radical concentrations for FREETEX' 96 , '98 and '01 and this work for all days and for "snow free" days. Errors quoted are $95 \%$ confidence limits.

\begin{tabular}{llc}
\hline Date & Campaign & $\begin{array}{c}\text { Mean mid day } \\
\text { peroxy radicals/pptv }\end{array}$ \\
\hline mid-Feb-mid-Mar & FREETEX'01 & $7 \pm 3^{\mathrm{a}}$ \\
mid-Mar-mid-Apr & FREETEX'98 & $13 \pm 3^{\mathrm{a}}$ \\
mid-Apr-mid-May & FREETEX'96 & $17 \pm 2^{\mathrm{a}}$ \\
end-Aug-mid-Sept & This work - "snow free" days & $19 \pm 5$ \\
end-Aug-mid-Sept & This work - all days & $13 \pm 4$ \\
\hline
\end{tabular}

a Zanis et al. (2003).

a)

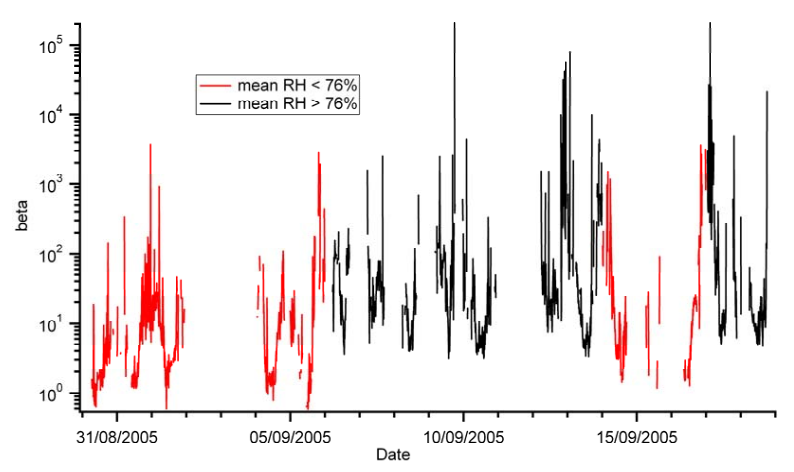

b)

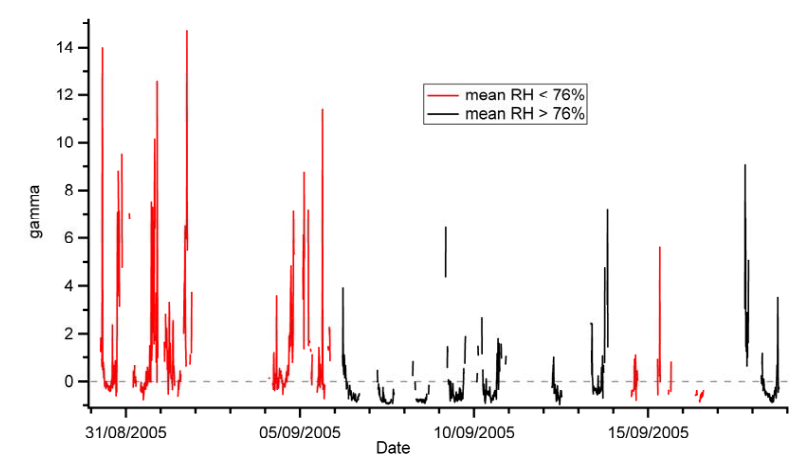

Fig. 5. (a) Time series of $\beta$ (for definition see text); (b) time series of $\gamma$ (for definition see text).

The inclusion of acetylperoxy at $\delta=0.5$ has a dramatic affect on $\gamma-\gamma$ for "snow free" days is increased from $\gamma=0.19$ to $\gamma=0.92$, and for "snowy" days $\gamma$ is increased from $\gamma=-0.49$ to $\gamma=-0.24$. Thus it can be seen that even with the questionable assumption of half of the organic peroxy radicals present being peroxyacetyl the increase in loss rate due to peroxy radical self-reaction is not enough to account for the negative $\gamma$ observed. In fact, the atmosphere at the Jungfraujoch is relatively clean. Figure 6 shows the percent-

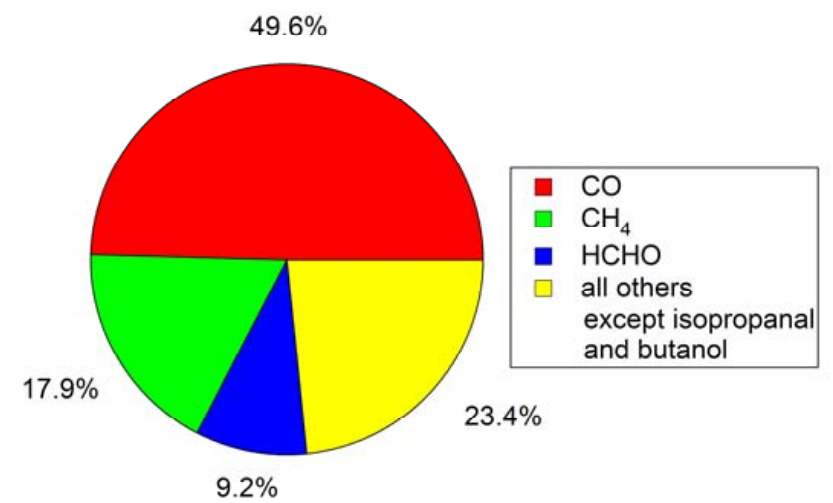

Fig. 6. Relative contributions to $\mathrm{OH}$ loss (with isopropanal and butanol excluded, see text).

age loss of $\mathrm{OH}$ due to $\mathrm{CO}, \mathrm{CH}_{4}, \mathrm{HCHO}$ and all other VOCs and OVOCs, as defined by the sum of the median values of $k_{\mathrm{OH}}[\mathrm{VOC}]$ of interest divided by the sum of median values of $k_{\mathrm{OH}}[\mathrm{VOC}]$ for all species, where $k_{\mathrm{OH}}$ is the rate of reaction of the VOC with $\mathrm{OH}$. Isopropanal and butanol are excluded as they are both in common use at Jungfraujoch and thus their measurements may be contaminated.

Nonetheless, even if there were a significant proportion of non-methyl fast reaction organic peroxy radicals present, $\gamma$ is still significantly negative for "snowy" days, indicating a missing loss term. To investigate the missing loss term, Eq. (1) has been rearranged and expanded for $\gamma$ to include an extra loss term $L_{e x}$, thus

$\gamma=\left(\frac{\left[\mathrm{HO}_{2}+\Sigma_{i} \mathrm{R}_{i} \mathrm{O}_{2}\right]^{2} \cdot \alpha \cdot(1+\beta) \cdot k_{\mathrm{self}}+L_{e x} / 2}{f \cdot j\left(\mathrm{O}^{1} \mathrm{D}\right) \cdot\left[\mathrm{O}_{3}\right]}\right)-1$

where

$L_{e x}=k_{e x}\left[\mathrm{HO}_{2}+\Sigma_{i} \mathrm{R}_{i} \mathrm{O}_{2}\right]$

In order to obtain $\gamma=0$ for "snowy" days from Eq. (7), $k_{e x}$ was adjusted until the median value of $\gamma$ for "snowy" days became zero. As such, $k_{e x}$ is a pseudo first order rate constant 
that incorporates all extra loss processes after peroxy radical self-reaction losses and loss through reaction with $\mathrm{NO}_{\mathrm{x}}$. To obtain median $\gamma=0$ for "snowy" days, $k_{e x}$ was set so that $k_{e x}=0.0063 \mathrm{~s}^{-1}$. It is worth reiterating here that $\alpha$ has been set to 0.5. Altering $\alpha$ by \pm 0.25 results in the value of $\gamma$ changing by $\pm 13 \%$, but not its sign. This clearly results in a change in the magnitude of $k_{e x}$ but not its existence. A question then arises as to the origin of these extra "losses".

One possibility is heterogeneous losses on the snow particles. Previous studies have outlined the potential importance of $\mathrm{HO}_{2}$ uptake on aerosol particles in the marine boundary layer (Haggerstone et al., 2005), on water (Hanson et al., 1992; Morita et al., 2004), on water ice (Cooper and Abbatt, 1996), and on aqueous sulphate aerosol (Cooper and Abbatt, 1996; Thornton and Abbatt, 2005) amongst others. Aerosol uptake of $\mathrm{HO}_{2}$ has been invoked to explain model overestimation of measured values (Smith et al., 2006; Sommariva et al., 2006, 2004) as has cloud processing (Olson et al., 2004). There have been suggestions of falling ice crystals scavenging aerosols and gases absorbing onto the crystal surface or even diffusing into its bulk (Grannas et al., 2007). However, there have been no reported studies of the loss or otherwise of $\mathrm{HO}_{2}$ on snow.

A simple calculation has been performed using the free molecular equation to calculate a lower limit for the surface area of snow per volume required to produce the observed loss rate.

$k_{\text {het }}=($ Surface Area $* v * \gamma) / 4$

where $v=$ mean molecular velocity and $\gamma$ is the uptake coefficient.

Using our value for $k_{\text {het }}\left(0.0063 \mathrm{~s}^{-1}\right), \gamma$ at the limiting value of 1 and $v$ calculated for $\mathrm{HO}_{2}$, we obtain a minimum surface area of $5.9 \times 10^{-5} \mathrm{~m}$.

The measured surface area of snow various widely with fresh snow generally having higher surface areas (Kerbrat et al., 2008). The $\gamma$ here chosen of 1 is the upper limit, and in reality will not be this high. However, this does serve to show that the required surface area for the loss rate derived is not "before too high."

\subsection{Additional peroxy radical production sources}

It has been seen that the median of $\gamma$ is greater than zero for "snow free" days, thereby signifying an additional production route over ozone photolysis. This additional production is significant with $\gamma=0.19$, and could come from a variety of sources including ozonolysis of alkenes, $\mathrm{NO}_{3}$ oxidation of alkenes and the photolysis of species such as $\mathrm{HCHO}, \mathrm{HONO}$ and $\mathrm{H}_{2} \mathrm{O}_{2} . \mathrm{NO}_{3}$ oxidation of alkenes is only significant at night due to the rapid photolysis of $\mathrm{NO}_{3}$ by sunlight (Monks, 2005) save for in very polluted atmospheres where daytime $\mathrm{NO}_{3}$ can become important (Geyer et al., 2003). Unfortunately $\mathrm{HONO}$ and $\mathrm{NO}_{3}$ were not measured during this campaign, so it is not possible to determine the possible contribu- tion they make to peroxy radical concentrations. In addition there were very sparse measurements of alkenes, so it is not possible to estimate the contribution of alkene ozonolysis to peroxy radical concentrations.

Formaldehyde and $j(\mathrm{HCHO})$ were measured during the campaign. The median production rate from the radical production channel of $\mathrm{HCHO}$ photolysis on the "snow free" days where $\mathrm{HCHO}$ measurements are available show that formaldehyde contributes up to $13.7 \%$ as much as the median production from ozone photolysis on the same days. This corresponds to 0.14 of the total $\gamma$ of 0.19 , and as such suggests that photolysis of formaldehyde is the most significant radical production source other than ozone photolysis. Furthermore, uncertainty in the measured $\mathrm{HCHO}$ is not sufficient to explain the remaining production. Ren et al. (2008) have reported that the photolysis of $\mathrm{H}_{2} \mathrm{O}_{2}$ can be a bigger contributor to $\mathrm{HO}_{\mathrm{x}}$ than $\mathrm{HCHO}$ at these altitudes. $\mathrm{H}_{2} \mathrm{O}_{2}$ was not measured during this campaign, however a concentration of 500 pptv $\mathrm{H}_{2} \mathrm{O}_{2}$ is sufficient to generate the remaining 0.05 of the total $\gamma . \mathrm{H}_{2} \mathrm{O}_{2}$ measurements at the Jungfraujoch are scarce, but the mean $\mathrm{H}_{2} \mathrm{O}_{2}$ of $206 \pm 261$ pptv measured by Walker et al. (2006) during February and March 2003 suggests that this is not out of the question.

\subsection{Seasonality}

Previous peroxy radical measurements have been made at the Jungfraujoch in April and May 1996 during the Free Tropospheric Experiment 1996 (FREETEX'96) (Zanis et al., 1999, 2000b), in March and April 1998 during Free Tropospheric Experiment 1998 (FREETEX'98) (Carpenter et al., 2000; Zanis et al., 2000a) and in February and March 2001 during Free Tropospheric Experiment 2001 (FREETEX'01) (Zanis et al., 2003).

The mean daytime maximum peroxy radical concentration as reported by Zanis et al. (2003) for FREETEX'96, '98, and '01 along with the mean daytime maximum peroxy radical concentration for all days and for "snow free" days for this campaign are presented in Table 4 along with the average diurnal cycle for peroxy radicals from FREETEX'96, '98 and '01 (Zanis et al., 2003) and all days and "snow free" days from this work in Fig. 7.

It can be seen that the gradual seasonal increase in maximum mean daily peroxy radicals observed by Zanis et al. (2003) continues through to the data taken during this work if only "snow free" days are considered. However, if all days are considered then there is a decrease back to the maximum mean seen in mid-March to mid-April. The main driving force for the seasonal trend in peroxy radicals are the production terms, with $j\left(\mathrm{O}^{1} \mathrm{D}\right)$ being the dominant factor (as discussed in Zanis et al., 2003).

Zanis et al. (2000a) calculated theoretical peroxy radical concentrations for the 15th of each month using a simple $\mathrm{CO} / \mathrm{CH}_{4}$ box model constrained by climatological monthly mean values of $\mathrm{O}_{3}, \mathrm{NO}_{\mathrm{x}}, \mathrm{H}_{2} \mathrm{O}$, temperature and pressure 


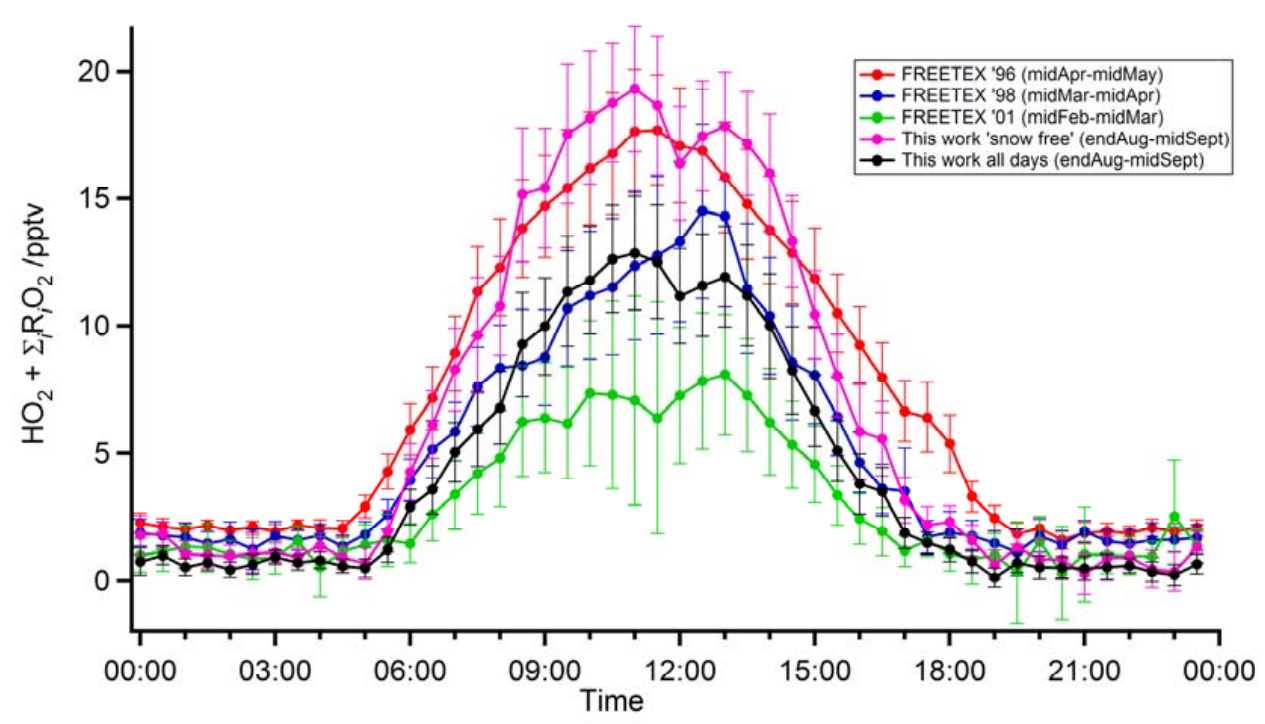

Fig. 7. Mean diurnal cycle for peroxy radicals from FREETEX'96, '98 and '01 (Zanis et al., 2003) and all days and "snow free" days from this work.

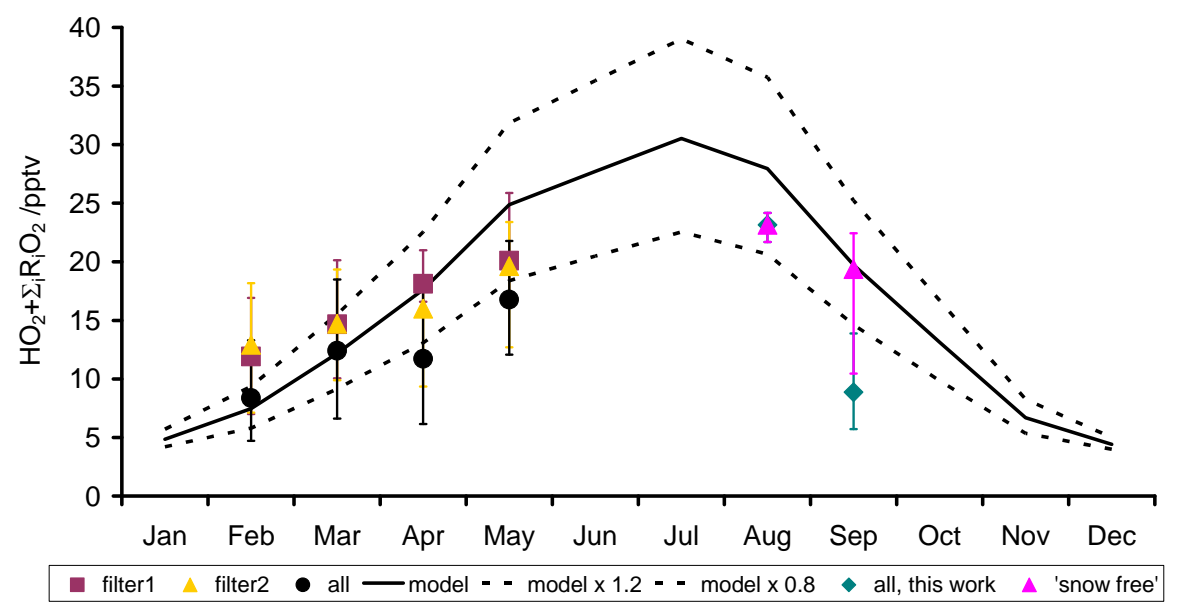

Fig. 8. Monthly median peroxy radical concentrations for all days during FREETEX, and filtered by two different methods (see text), with data recorded during this work for all days and for "snow free" days. Error bars represent the first and third quartiles. Monthly model value on the 15th of each month is shown as a solid line, dashed lines represent model sensitivity to $20 \%$ changes in $\mathrm{O}_{3}, \mathrm{H}_{2} \mathrm{O}, \mathrm{NO}_{\mathrm{x}}$ and photolysis rates.

measured at Jungfraujoch from 1992-1996. The modelled results were compared with monthly median values of measured peroxy radicals between 10:00 UTC and 13:00 UTC (a symmetric window around local noon).

Figure 8 shows monthly median peroxy radical concentrations as reported in Zanis et al. (2003) for all days during FREETEX, and FREETEX data filtered by two different methods, in addition to the data recorded during this work for all days and for "snow free" days. For filter 1, days were selected where the daily median global radiation was higher than the median global radiation for the respective campaign. For filter 2 , measured half-hourly $j\left(\mathrm{O}^{1} \mathrm{D}\right)$ values were compared to theoretical ones in order to decide on a half-hour average whether values were impacted by clouds. Measured values more than $30 \%$ lower than theoretical ones were filtered out. For details see Zanis et al. (2003). The error bars represent the first and third quartiles. The model value on the 15 th of each month as described above is shown as a solid line and the dashed lines represent the model sensitivity to $20 \%$ changes in $\mathrm{O}_{3}, \mathrm{H}_{2} \mathrm{O}, \mathrm{NO}_{\mathrm{x}}$ and photolysis rates. 


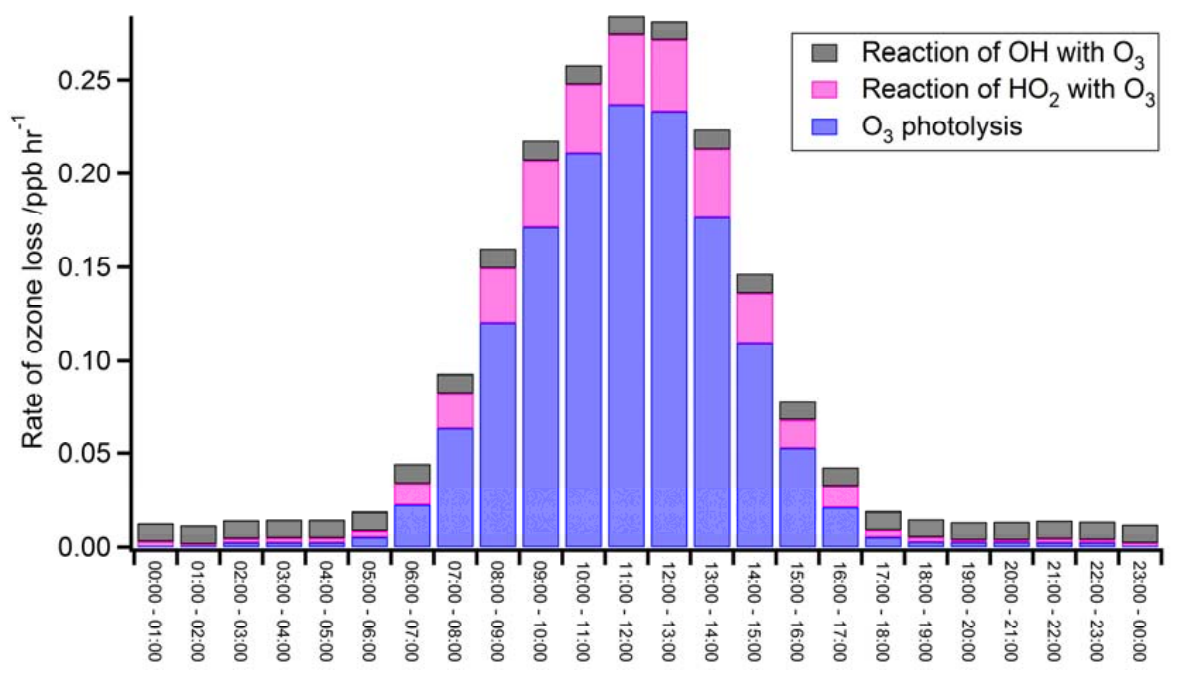

Fig. 9. Relative contributions of ozone loss terms to total $L\left(\mathrm{O}_{3}\right)$.

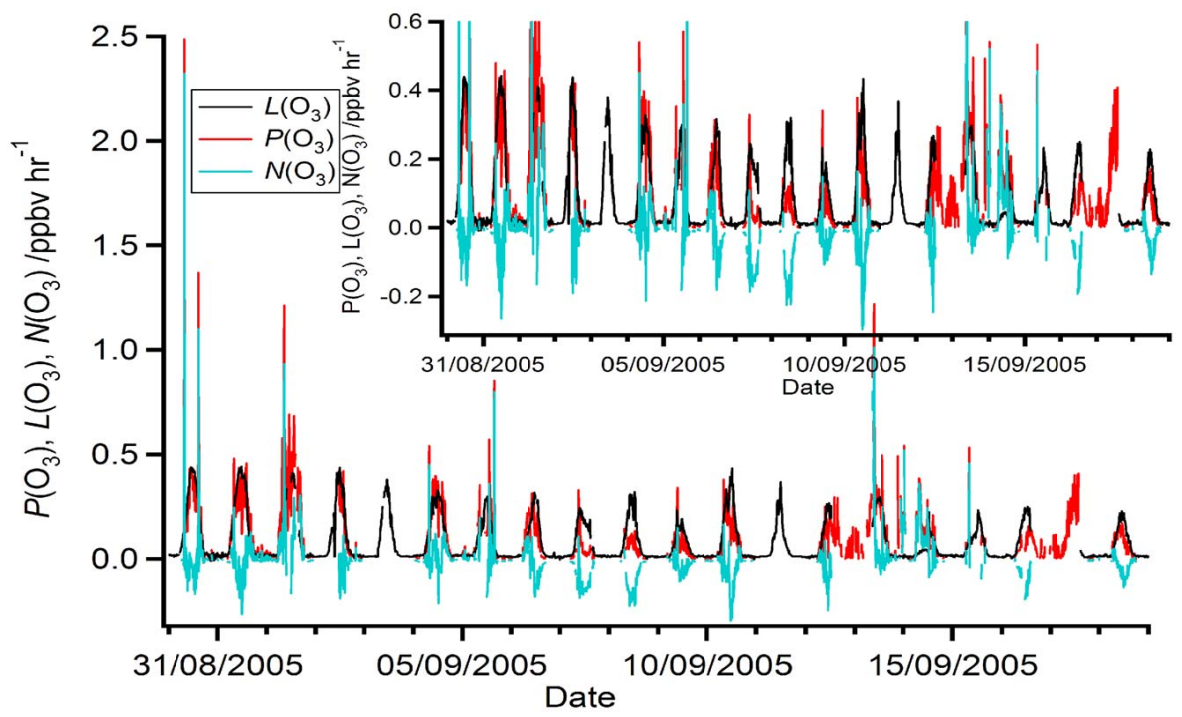

Fig. 10. Time series of $P\left(\mathrm{O}_{3}\right), L\left(\mathrm{O}_{3}\right)$ and $N\left(\mathrm{O}_{3}\right)$.

The measured values show a good agreement with the simple box model used, indicating that in the relatively clean atmosphere of the Jungfraujoch a good theoretical understanding can be achieved purely by invoking $\mathrm{CO}$ and $\mathrm{CH}_{4}$ chemistry, despite $\mathrm{OH}$ reactivity calculations indicating that up to $32.5 \%$ of OH reactivity is because of species other than $\mathrm{CO}$ and $\mathrm{CH}_{4}$. It should be noted however that the measured monthly median peroxy radical concentrations for August only contain two days data (30 August 2005 and 31 August 2005), and thus care must be taken in extrapolating inferences too far.

\subsection{Ozone production and loss}

The net photochemical ozone production or loss gives a measure of instantaneous in-situ ozone production or loss within an air-mass and has been calculated from measured peroxy radicals, as,

$$
\begin{aligned}
\mathrm{N}(\mathrm{O})_{3} & =k_{c} \cdot\left[\mathrm{HO}_{2}+\mathrm{RO}_{2}\right] \cdot[\mathrm{NO}] \\
& -\left\{f \cdot j\left(\mathrm{O}^{1} \mathrm{D}\right)+K_{16}[\mathrm{OH}]+k_{17}\left[\mathrm{HO}_{2}\right]\right\}\left[\mathrm{O}_{3}\right]
\end{aligned}
$$

with $k_{c}$ representing the combined rate constant for oxidation of $\mathrm{NO}$ to $\mathrm{NO}_{2}$ by $\Sigma_{i} \mathrm{R}_{i} \mathrm{O}_{2}$ and $\mathrm{HO}_{2}$ (Reactions R1 and $\mathrm{R} 3)$ and $k_{16}$ and $k_{17}$ the reaction rate constants for Reactions (R16) and (R17), respectively.

$\mathrm{OH}+\mathrm{O}_{3} \rightarrow \mathrm{HO}_{2}+\mathrm{O}_{2}$ 
a)

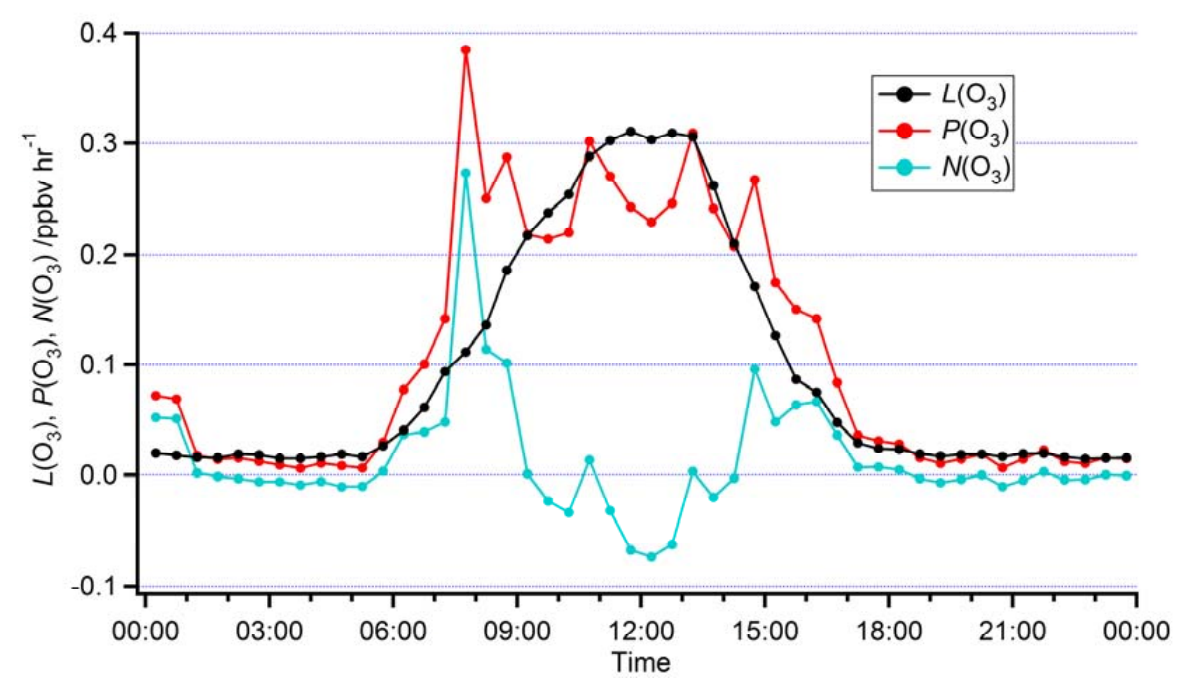

b)

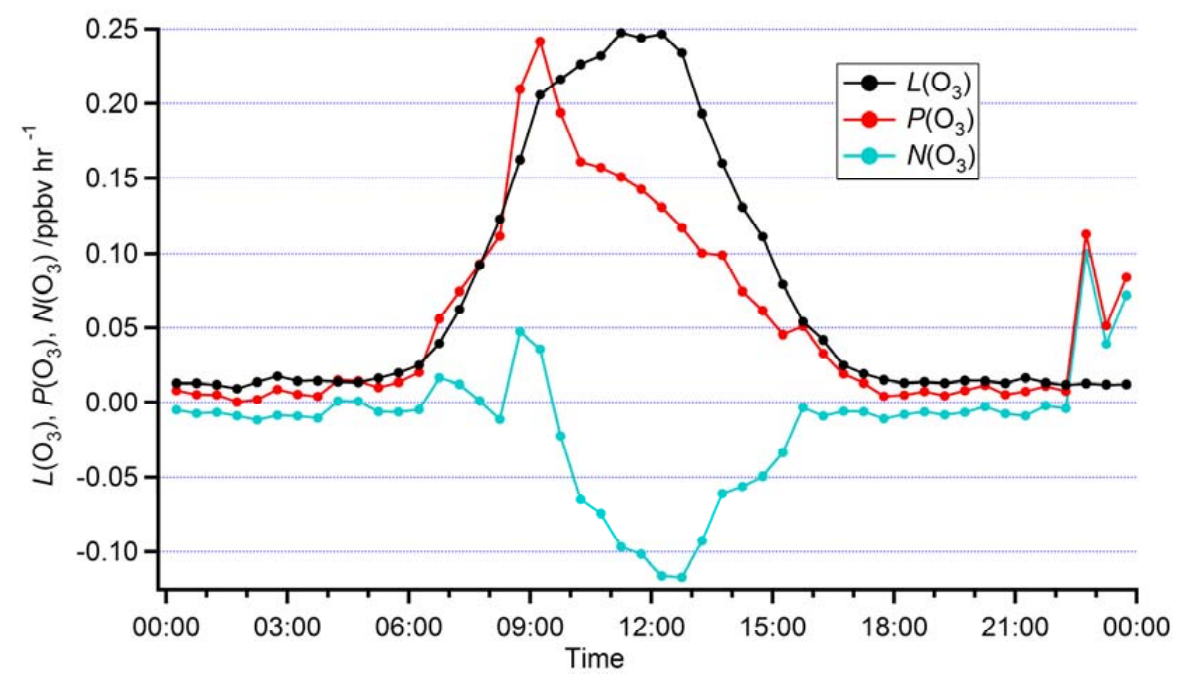

Fig. 11. (a) Mean diurnal cycle for $N\left(\mathrm{O}_{3}\right), P\left(\mathrm{O}_{3}\right)$ and $L\left(\mathrm{O}_{3}\right)$ on days classified as "snow free"; (b) mean diurnal cycle for $N\left(\mathrm{O}_{3}\right), P\left(\mathrm{O}_{3}\right)$ and $L\left(\mathrm{O}_{3}\right)$ on days classified as "snowy".

$\mathrm{HO}_{2}+\mathrm{O}_{3} \rightarrow \mathrm{OH}+2 \mathrm{O}_{2}$

The first term in Eq. (10) is the ozone production term and is the only known way of producing ozone in the troposphere in excess of the photostationary steady state between ozone and $\mathrm{NO}_{\mathrm{x}} \cdot \mathrm{NO}_{2}$ produced from the oxidation of $\mathrm{NO}$ by peroxy radicals in Reactions (R1) and (R3) is photolysed to produce oxygen atoms that then form ozone, viz,

$\mathrm{NO}_{2}+h v \rightarrow \mathrm{NO}+\mathrm{O}\left({ }^{3} \mathrm{P}\right)$
$\mathrm{O}\left({ }^{3} \mathrm{P}\right)+\mathrm{O}_{2}+\mathrm{M} \rightarrow \mathrm{O}_{3}+\mathrm{M}$

The other terms of Eq. (10) represent the loss processes of ozone in the troposphere, specifically the photolysis of ozone to form excited ozone atoms multiplied by $f$, the proportion of $\mathrm{O}\left({ }^{1} \mathrm{D}\right)$ that then react with water vapour, the reaction of ozone with $\mathrm{OH}$ (Reaction R16), and the reaction of ozone with $\mathrm{HO}_{2}$ (Reaction R17).

The net ozone production or loss rate calculated by Eq. (10) contains a number of assumptions such as neglecting 


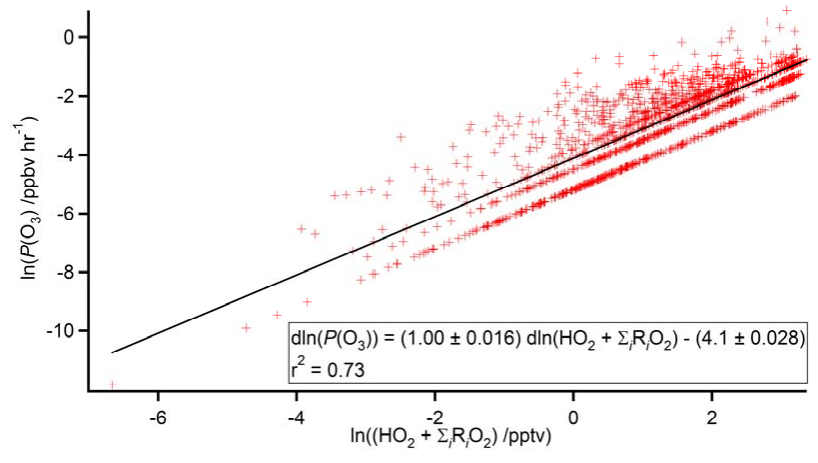

Fig. 12. Correlation between $\ln \left(P\left(\mathrm{O}_{3}\right)\right)$ and $\ln$ (peroxy radicals).

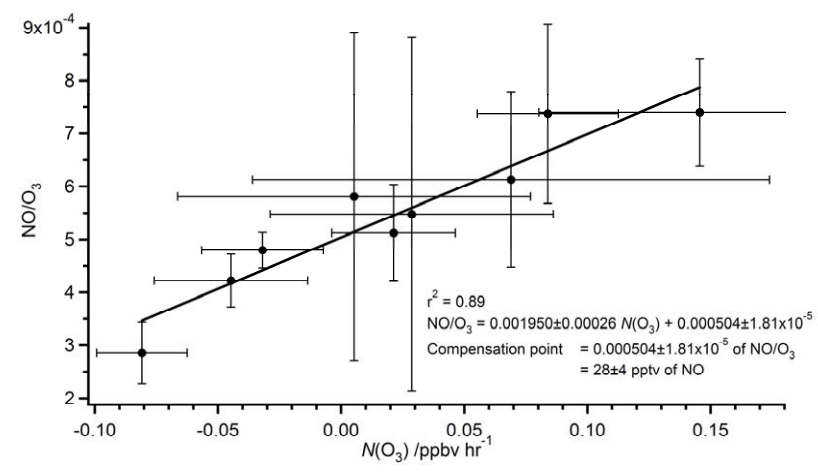

Fig. 13. Daily averaged $\mathrm{NO} / \mathrm{O}_{3}$ plotted against the respective daily mean $N\left(\mathrm{O}_{3}\right)$. The error bars represent $95 \%$ confidence limits.

cloud processes, dry deposition, and reactions with alkenes and halogens. Nevertheless, Eq. (10) remains a good approximation for the free troposphere.

$\mathrm{OH}$ and $\mathrm{HO}_{2}$ were not measured discretely during this work, and so assumptions have to be made about their concentrations. In this work $\alpha$ has been taken as 0.5 and the concentration of $\mathrm{OH}$ radicals has been taken at $1 \times 10^{6}$ molecules $\mathrm{cm}^{-3}$. It can be seen from Fig. 9 that the relative contribution of the $\mathrm{OH}$ loss term is small during daytime, and as such $L\left(\mathrm{O}_{3}\right)$ is relatively insensitive to $\mathrm{OH}$ concentration.

It has recently been suggested by Wood (2008) that the ozone production term should be corrected to account for the fraction of $\mathrm{NO}_{2}$ that reacts with $\mathrm{OH}$ rather than photolyses. For this dataset with an $\mathrm{OH}$ concentration of $1 \times 10^{6}$ molecules $\mathrm{cm}^{-3}$ the daytime correction factor is greater than approximately 0.997 and thus has been neglected.

A time series for the resultant $P\left(\mathrm{O}_{3}\right), L\left(\mathrm{O}_{3}\right)$ and $N\left(\mathrm{O}_{3}\right)$ are shown in Fig. 10. It can be seen that overall the airmasses encountered during the time of this campaign were almost net neutral in terms of ozone production, with a median $N\left(\mathrm{O}_{3}\right)$ for the entire time series of $-0.01 \mathrm{ppb} \mathrm{h}^{-1}$ and a mean $N\left(\mathrm{O}_{3}\right)$ of $0.00 \mathrm{ppb} \mathrm{h}^{-1}$.
Table 5. Details of $N\left(\mathrm{O}_{3}\right)$ for "snow free" and "snowy" days.

\begin{tabular}{lrr}
\hline & \multicolumn{2}{c}{$N\left(\mathrm{O}_{3}\right) / \mathrm{ppbv} \mathrm{h}^{-1}$} \\
& "snow free" & "snowy" \\
\hline Median & -0.01 & -0.02 \\
Mean & 0.02 & -0.03 \\
Standard deviation & 0.16 & 0.10 \\
10th percentile & -0.09 & -0.14 \\
90th percentile & 0.11 & 0.03 \\
\hline
\end{tabular}

If the days are split into "snow free" and "snowy" it can be seen that the "snowy" days are generally more net ozone destructive. Table 5 details the median, mean, standard deviation and 10th and 90th percentiles for "snowy" and "snow free" days.

Mean diurnal cycles also highlight the differences between the two sets of days, as illustrated in Fig. 11a and b. It can be seen that there is a much larger difference in $P\left(\mathrm{O}_{3}\right)$ between the two sets of days than there is in $L\left(\mathrm{O}_{3}\right)$, and it is this that is driving the increase in net ozone loss on "snowy" days.

The $P\left(\mathrm{O}_{3}\right)$ is itself driven by peroxy radicals throughout the measurement campaign, as evidenced in Fig. 12 where a plot of natural $\log$ of $P\left(\mathrm{O}_{3}\right)$ with the natural log of peroxy radical concentration shows a good correlation $\left(r^{2}=0.73\right)$. In contrast the correlation between natural $\log$ of $P\left(\mathrm{O}_{3}\right)$ and natural $\log$ of $\mathrm{NO}$ is poor, with $r^{2}=0.27$. As a result, the increased net ozone loss seen on "snowy days" compared to "snow free" days is primarily due to the reduction of peroxy radicals on "snowy days".

An early morning peak in $P\left(\mathrm{O}_{3}\right)$ can be seen in Fig. 11a and $\mathrm{b}$, which is as a result of a corresponding peak in NO. The peak in NO is at a similar time to when $j(\mathrm{HONO})$ is starting to increase, and could be because of an overnight build up of HONO which is then photolysed to provide the burst of NO seen. Unfortunately, HONO was not measured during this campaign and therefore it is not possible to quantify the magnitude of $\mathrm{NO}$ production from $\mathrm{HONO}$ photolysis.

\subsection{Ozone compensation point}

The ozone compensation point is the concentration of $\mathrm{NO}$ at which $N\left(\mathrm{O}_{3}\right)$ becomes zero, i.e. the point at which in-situ ozone production matches in-situ loss (Zanis et al., 2000a). To this end, Fig. 13 is a plot of daily averaged $\mathrm{NO} / \mathrm{O}_{3}$ plotted against the respective daily mean $N\left(\mathrm{O}_{3}\right)$ during the times 06:00 UTC to 16:30 UTC for "snow free" days. The times of 06:00 UTC to 16:30 UTC correspond to the period of the day where instantaneous $j\left(\mathrm{O}^{1} \mathrm{D}\right)$ is greater than $5 \%$ of the daily maximum $j\left(\mathrm{O}^{1} \mathrm{D}\right)$. The error bars represent $95 \%$ confidence limits and a linear fit has been performed. The correlation is good $\left(r^{2}=0.89\right)$, and from the linear fit a value of $\mathrm{NO} / \mathrm{O}_{3}=0.000504 \pm 1.81 \times 10^{-5}$ has been obtained when 
$N\left(\mathrm{O}_{3}\right)=0$. Using the mean ozone concentration for the period during which $N\left(\mathrm{O}_{3}\right)$ and $\mathrm{NO} / \mathrm{O}_{3}$ data has been plotted, a value of $28 \pm 4$ pptv of $\mathrm{NO}$ is obtained as an estimate for the ozone compensation point. This suggests that in the conditions experienced on "snow free" days at the Jungfraujoch in late August and early September, a NO concentration of greater than approximately $28 \mathrm{pptv}$ is required in order for net in-situ ozone production to occur.

\subsection{Comparison with previous results}

Ozone production rates were calculated by Zanis et al. (2003) for FREETEX' 96, '98 and '01, although an estimate of NO derived from monthly median concentrations from 10:00 UTC to 13:00 UTC for 1992-1995 had to be used for FREETEX'96 as NO measurements were not performed. Reported values for $N\left(\mathrm{O}_{3}\right)$ range from $0.1 \mathrm{ppbvh}^{-1}$ to $0.4 \mathrm{ppbv} \mathrm{h}^{-1}$ for monthly median values from 10:00 UTC to 13:00 UTC from late Winter to late Spring. For the same daily time period, the median $N\left(\mathrm{O}_{3}\right)$ measured for "snow free" days was $-0.05 \mathrm{ppbh}^{-1}$. The median NO concentration measured during this work for "snow free" days between 10:00 UTC and 13:00 UTC was low at 30 pptv compared to the values quoted in Zanis et al. (2003) of $56 \mathrm{pptv}$ in February during FREETEX'01, 34 pptv in March during FREETEX'98 and '01, $67 \mathrm{pptv}$ (estimated as detailed above) in April during FREETEX'96 and 65 pptv (estimated as detailed above) in May during FREETEX'96. The low concentrations of $\mathrm{NO}$ contribute to the reduced $N\left(\mathrm{O}_{3}\right)$ on "snow free" days from 10:00 to 13:00 UTC, as during these periods peroxy radical concentrations are relatively high and in contrast to the campaign as a whole $P\left(\mathrm{O}_{3}\right)$ is not solely peroxy radical limited but also NO limited.

The median concentration of NO on "snow free" days between 10:00 UTC and 13:00 UTC of 30 pptv is similar to the calculated ozone compensation point for "snow free" days of $28 \pm 4$ pptv of $\mathrm{NO}$, and helps to illustrate why $N\left(\mathrm{O}_{3}\right)$ is marginally negative during this period. In contrast, $\mathrm{Za}$ nis et al. (2000a) calculated an ozone compensation point of $24 \pm 9$ pptv of NO during FREETEX' 98 when median monthly NO was 34 pptv and saw positive monthly median $N\left(\mathrm{O}_{3}\right)$ (Zanis et al., 2003).

\section{Conclusions}

The sum of peroxy radicals has been measured with the peroxy radical chemical amplification (PERCA) technique for a period from 30 August 2005 to 18 September 2005 inclusive along with a range of photolysis rates and supporting measurements. During the measurement period two contrasting periods of weather were encountered - days on which heavy snowfall occurred and those on which it did not, defined herein as having a daily mean relative humidity of greater than $76 \%$. The relative peroxy radical concentrations were very different during the two periods, with peroxy radicals significantly suppressed during "snowy" days compared to "snow free" days by up to a factor of 3 or more. $j\left(\mathrm{O}^{1} \mathrm{D}\right)$ was also reduced during the "snowy" days, but not to the extent of peroxy radicals. In contrast ozone and $\mathrm{CO}$ are neither significantly suppressed nor enhanced, while $\mathrm{NO}, \mathrm{NO}_{2}, \mathrm{HCHO}$ and PAN were all enhanced during the "snowy" days.

A $\beta$ and $\gamma$ analysis as per Mihele and Hastie (2003) was carried out to investigate the origin of the suppression of peroxy radicals. The calculated median $\gamma$ for "snowy" days is -0.49 , indicating that neither the increased $\mathrm{NO}_{\mathrm{x}}$ nor reduced $j\left(\mathrm{O}^{1} \mathrm{D}\right)$ can account for the suppression of peroxy radicals witnessed, and that there must be an unaccounted loss term present. A fast reacting peroxy radical (acetylperoxy) was introduced at half the total concentration of $\Sigma_{i} R_{i} \mathrm{O}_{2}$ to investigate the effect of the presence of a fast reacting peroxy radical. However, the introduction of acetylperoxy resulted in $\gamma=-0.24$, indicating another loss term was still required to explain the discrepancy. In order to obtain median calculated $\gamma=0$ (with no acetylperoxy present), a pseudo first order loss rate of $k_{e x}=0.0063 \mathrm{~s}^{-1}$ is required. It is speculated that this excess loss could be from heterogeneous processing on snow particles.

In contrast median $\gamma$ for "snow free" days is 0.19 , indicating that on these days there is some excess radical production over that from ozone photolysis. Whilst possible sources include HONO photolysis (especially early in the morning) or oxidation of alkenes by ozone or $\mathrm{NO}_{3}$ (especially at night), calculations of the photolysis of HCHO to produce radical products suggests that this route could account for up to 0.137 of the $\gamma=0.19$.

The seasonal trends of peroxy radicals have been investigated in conjunction with data from the previous field campaigns FREETEX'96 (Zanis et al., 1999, 2000b), FREETEX'98 (Carpenter et al., 2000; Zanis et al., 2000a) and FREETEX'01 (Zanis et al., 2003). The mean midday "snow free" peroxy radical concentrations are marginally higher than the concentration measured during FREETEX'96 in mid-April to mid-May, whereas if all days are considered the mean midday peroxy radical concentration recorded during this campaign is similar to that recorded during FREETEX'98 in mid-March to mid-April. The monthly median peroxy radical concentration between the hours of 10:00 to 13:00 UTC has been compared both with previous data and a simple box model as reported by Zanis et al. (2003) and shows good agreement for "snow free" days, but the model overestimates measured values when all days are taken into account, which could be explained by a missing loss term in the model as with the $\gamma$ analysis.

Net ozone production rates have been calculated that show that overall the conditions encountered during this work at the Jungfraujoch were net neutral to marginally ozone destructive. Days during the snowfall period were more net ozone destructive than "snow free" days, mainly due to reduced ozone production rather than increased ozone loss 
rates. Overall ozone production through the campaign was peroxy radical limited, except for a limited period around noon on "snow free" days where low NO concentrations (median NO concentration was $30 \mathrm{pptv}$ ) and moderate peroxy radical concentrations (median peroxy radical concentration was 21 pptv) were experienced and ozone production was limited by both peroxy radicals and NO. The ozone compensation point was calculated for "snow free" days during the campaign and suggests that under the conditions experienced a NO concentration of greater than approximately $28 \mathrm{pptv}$ is required in order for net in-situ ozone production to occur.

The monthly median net ozone production on "snow free" days between 10:00 UTC and 13:00 UTC is lower than that calculated by Zanis et al. (2003) for, and can be explained by the lower concentrations of NO for the same time period seen in this work compared to that seen by Zanis et al. (2003) from late Winter to late Spring. Whilst ozone production for this campaign in general is peroxy radical limited, during the times of 10:00 UTC and 13:00 UTC on "snow free" days ozone production is limited by both peroxy radicals and NO.

Acknowledgements. The authors would like to thank the University of Leicester Chemistry Electrical and Mechanical workshops, especially P. Acton, G. Butler, K. Wilkinson and R. Batchen for instrument construction. The work of J. Balzani-Lööv was supported by a grant of the Swiss National Science Foundation. The authors are grateful to S. Henne from EMPA for the provision of the trajectory analysis. We acknowledge that the International Foundation High Altitude Research Stations Jungfraujoch and Gornergrat (HFSJG), 3012 Bern, Switzerland, made it possible for us to carry out our experiment(s) at the High Altitude Research Station at Jungfraujoch. We are particularly grateful to the JFJ custodians for their support of the work. We further acknowledge the EU ACCENT project for support through its Access to Infrastructure program. The Swiss National Air Pollution Monitoring Network (NABEL) is operated by Empa in joint collaboration with the Swiss Federal Office for The Environment.

Edited by: R. Cohen

\section{References}

Atkinson, R., Baulch, D. L., Cox, R. A., Hampson, R. F., Kerr, J. A., Rossi, M. J., and Troe, J.: Evaluated kinetic and photochemical data for atmospheric chemistry, organic species: Supplement VII, J. Phys. Chem. Ref. Data, 28, 191-393, 1999.

Atkinson, R., Baulch, D. L., Cox, R. A., Crowley, J. N., Hampson, R. F., Hynes, R. G., Jenkin, M. E., Rossi, M. J., and Troe, J.: Evaluated kinetic and photochemical data for atmospheric chemistry: Volume $\mathrm{I}-$ gas phase reactions of $\mathrm{O}_{\mathrm{x}}, \mathrm{HO}_{\mathrm{x}}, \mathrm{NO}_{\mathrm{x}}$ and $\mathrm{SO}_{\mathrm{x}}$ species, Atmos. Chem. Phys., 4, 1461-1738, 2004, http://www.atmos-chem-phys.net/4/1461/2004/.

Balzani Lööv, J. M., Legreid, G., Staehelin, J., Reimann, S., Prévôt, A. S. H., Henne, S., and Steinbacher, M.: Seasonal background concentration variations of selected trace gases at the Swiss high Alpine station Jungfraujoch during 2005, unpublished manuscript, 2007.
Bongartz, A., Kames, J., Welter, F., and Schurath, U.:, Near-UV absorption cross-sections and trans cis equilibrium of nitrous acid, J. Phys. Chem., 95, 1076-1082, 1991.

Cantrell, C. A. and Stedman, D. H.: A possible technique for the measurement of atmospheric peroxy-radicals, Geophys. Res. Lett., 9, 846-849, 1982.

Cantrell, C. A., Stedman, D. H., and Wendel, G. J.: Measurement of atmospheric peroxy-radicals by chemical amplification, Anal. Chem., 56, 1496-1502, 1984.

Cantrell, C. A., Shetter, R. E., Calvert, J. G., Parrish, D. D., Fehsenfeld, F. C., Goldan, P. D., Kuster, W., Williams, E. J., Westberg, H. H., Allwine, G., and Martin, R.: Peroxy-radicals as measured in rose and estimated from photostationary state deviations, J. Geophys. Res.-Atmos., 98, 18355-18366, 1993.

Cantrell, C. A., Edwards, G. D., Stephens, S., Mauldin, L., Kosciuch, E., Zondlo, M., and Eisele, F. Peroxy radical observations using chemical ionization mass spectrometry during TOPSE, J. Geophys. Res.-Atmos., 108, 8371, doi:10.1029/2002JD002715, 2003.

Carpenter, L. J., Green, T. J., Mills, G. P., Baugitte, S., Penkett, S. A., Zanis, P., Schuepbach, E., Schmidbauer, N., Monks, P. S., and Zellweger, C.: Oxidized nitrogen and ozone production effeciencies in the springtime free troposphere over the Alps, J. Geophys. Res., 105, 14547-14559, 2000.

Clemitshaw, K. C., Carpenter, L. J., Penkett, S. A., and Jenkin, M. E.: A calibrated peroxy radical chemical amplifier (PERCA) for ground-based measurements in the troposphere, J. Geophys. Res., 102, 25405-25416, 1997.

Cooper, P. and Abbatt, J. P. D.: Heterogeneous Interactions of $\mathrm{OH}$ and $\mathrm{HO}_{2}$ Radicals with Surfaces Characteristic of Atmospheric Particulate Matter, J. Phys. Chem., 100, 2249-2254, 1996.

Coquart, B., Jenouvrier, A., and Merienne, M. F.: The $\mathrm{NO}_{2}$ absorption spectrum. II. Aborption cross-sections at low temperatures in the 400-500 nm region, J. Atmos. Chem., 21, 251-261, 1995.

Dommen, J., Prévôt, A. S. H., Neininger, B., and Bäumle, M.: Characterization of the photooxidant formation in the metropolitan area of Milan from aircraft measurements, J. Geophys. Res., 107, 8197, doi:10.1029/2000JD000283, 2002.

Edwards, G. D., Cantrell, C. A., Stephens, S., Hill, B., Goyea, O., Shetter, R. E., Mauldin III, R. L., Kosciuch, E., Tanner, D. J., and Eisele, F. L.: Chemical ionization mass spectrometer instrument for the measurement of tropospheric $\mathrm{HO}_{2}$ and $\mathrm{RO}_{2}$, Anal. Chem., 75, 5317-5327, 2003.

Edwards, G. D. and Monks, P. S.: Performance of a singlemonochromator diode array spectroradiometer for the determination of actinic flux and atmospheric photolysis frequencies, J. Geophys. Res., 108, 8546, doi:10.1029/2002JD002844, 2003.

Europe, E. C.: Hemispheric transport of air pollution 2007, United Nations, Geneva, Switzerland, 2008.

Fleming, Z. L., Monks, P. S., Rickard, A. R., Bandy, B. J., Brough, N., Green, T. J., Reeves, C. E., and Penkett, S. A.: Seasonal dependence of peroxy radical concentrations at a Northern hemisphere marine boundary layer site during summer and winter: evidence for radical activity in winter, Atmos. Chem. Phys., 6, 5415-5433, 2006a, http://www.atmos-chem-phys.net/6/5415/2006/.

Fleming, Z. L., Monks, P. S., Rickard, A. R., Heard, D. E., Bloss, W. J., Seakins, P. W., Still, T. J., Sommariva, R., Pilling, M. J., Morgan, R., Green, T. J., Brough, N., Mills, G. P., Penkett, S. 
A., Lewis, A. C., Lee, J. D., Saiz-Lopez, A., and Plane, J. M. C.: Peroxy radical chemistry and the control of ozone photochemistry at Mace Head, Ireland during the summer of 2002, Atmos. Chem. Phys., 6, 2193-2214, 2006b,

http://www.atmos-chem-phys.net/6/2193/2006/.

Geyer, A., Alicke, B., Ackermann, R., Martinez, M., Harder, H., Brune, W. H., di Carlo, P., Williams, E., Jobson, T., Hall, S., Shetter, R., and Stutz, J.: Direct observations of daytime $\mathrm{NO}_{3}$ : Implications for urban boundary layer chemistry, J. Geophys. Res., 108, 4368, doi:10.1029/2002JD002967, 2003.

Gierczak, T., Burkholder, J. B., Bauerle, S., and Ravishankara, A. R.: Photochemistry of acetone under tropospheric conditions, Chem. Phys., 231, 229-244, 1998.

Grannas, A. M., Jones, A. E., Dibb, J., Ammann, M., Anastasio, C., Beine, H. J., Bergin, M., Bottenheim, J., Boxe, C. S., Carver, G., Chen, G., Crawford, J. H., Dominé, F., Frey, M. M., Guzmán, M. I., Heard, D. E., Helmig, D., Hoffmann, M. R., Honrath, R. E., Huey, L. G., Hutterli, M., Jacobi, H. W., Klán, P., Lefer, B., McConnell, J., Plane, J., Sander, R., Savarino, J., Shepson, P. B., Simpson, W. R., Sodeau, J. R., von Glasow, R., Weller, R., Wolff, E. W., and Zhu, T.: An overview of snow photochemistry: evidence, mechanisms and impacts, Atmos. Chem. Phys., 7, 4329-4373, 2007,

http://www.atmos-chem-phys.net/7/4329/2007/.

Green, T. J., Reeves, C. E., Brough, N., Edwards, G. D., Monks, P. S., and Penkett, S. A.: Airborne measurements of peroxy radicals using the PERCA technique, J. Environ. Monitor., 5, 75-83, 2003.

Green, T. J., Reeves, C. E., Flemming, Z. L., Brough, N., Rickard, A. R., Bandy, B. J., Monks, P. S., and Penkett, S. A.: An improved dual channel PERCA instrument for atmospheric measurements of peroxy radicals, J. Environ. Monitor., 8, 530-536, 2006.

Haggerstone, A.-L., Carpenter, L. J., Carslaw, N., and McFiggans, G.: Improved model predictions of $\mathrm{HO}_{2}$ with gas to particle mass transfer rates calculated using aerosol number size distribution, J. Geophys. Res., 110, D04303, doi:10.1029/2004JD005282, 2005.

Hanson, D. R., Burkholder, J. B., Howard, C. J., and Ravishankara, A. R.: Measurement of hydroxyl and hydroperoxy radical uptake coefficients on water and sulfuric acid surfaces, J. Phys. Chem., 96, 4979-4985, 1992.

Heard, D. E. and Pilling, M. J.: Measurement of $\mathrm{OH}$ and $\mathrm{HO}_{2}$ in the Troposphere, Chem. Rev., 103, 5163-5198, 2003.

Kelly, T. J. and Fortune, C. R.: Continuous monitoring of formaldehyde using an improved fluorescence approach, Int. J. Environ. An. Ch., 54, 249-263, 1994.

Kerbrat, M., Pinzer, B., Huthwelker, T., Gäggeler, H. W., Ammann, A., Schneebeli, M.: Measuring the specific surface area of snow with X-ray tomography and gas adsorption: comparisona and implications for surface smoothness, Atmos. Chem. Phys., 8, 1261-1275, 2008, http://www.atmos-chem-phys.net/8/1261/2008/.

Legreid, G., Balzani-Lööv, J., Staehelin, J., Hueglin, C., Hill, M., Buchmann, B., Prevot, A. S. H., and Reimann, S.: Oxygenated Volatile Organic Compounds (OVOCs) at an urban background site in Zürich (Europe): Seasonal variation and source allocation, Atmos. Environ., 41, 8409-8423, 2007.

Legreid, G., Folini, D., Staehelin, J., Balzani Lööv, J., Steinbacher, M., and Reimann, S.: Measurements of organic trace gases including oxygenated volatile organic compounds at the high alpine site Jungfraujoch (Switzerland): Seasonal variation and source allocations, J. Geophys. Res.-Atmos., 113, D05307, doi:10.1029/2007JD008653, 2008.

Lugauer, M., Baltensperger, U., Furger, M., Gäggeler, H. W., Jost, D. T., Schwikowski, M., and Wanner, H.: Aerosol transport to the high Alpine sites Jungfraujoch (3454 m a.s.1.) and Colle Gnifetti (4452 m a.s.1.), Tellus B, 50, 76-92, 1998.

Malicet, J., Daumont, D., Charbonnier, J., Parisse, C., Chakir, A., and Brion, J.: Ozone UV spectroscopy. 2. Absorption crosssections and temperature-dependence, J. Atmos. Chem., 21, 263-273, 1995.

Martilli, A., Neftel, A., Favaro, G., Kirchner, F., Sillman, S., and Clappier, A.: Simulation of the ozone formation in the nortnern part of the Po Valley, J. Geophys. Res., 107, 8195, doi:10.1029/2001JD000534, 2002.

Matsumi, Y., Comes, F. J., Hancock, G., Hofzumahaus, A., Hynes, A. J., Kawasaki, M., and Ravishankara, A. R.: Quantum yields for production of $\mathrm{O}\left({ }^{1} \mathrm{D}\right)$ in the ultraviolet photolysis of ozone: Recommendation based on evaluation of laboratory data, J. Geophys. Res., 107, 4024, doi:10.1029/2001JD000510, 2002.

Meller, R. and Moortgat, G. K.: Temperature dependence of the absorption cross sections of formaldehyde between 223 and $323 \mathrm{~K}$ in the wavelength range $225-375 \mathrm{~nm}$, J. Geophys. Res., 105(D6), 7089-7101, doi:10.1029/1999JD901074, 2000.

Mihelcic, D., Holland, F., Hofzumahaus, A., Hoppe, L., Konrad, S., Musgen, P., Patz, H. W., Schafer, H. J., Schmitz, T., VolzThomas, A., Bachmann, K., Schlomski, S., Platt, U., Geyer, A., Alicke, B., and Moortgat, G. K.: Peroxy radicals during BERLIOZ at Pabstthum: Measurements, radical budgets and ozone production, J. Geophys. Res.-Atmos., 108, 8254, doi:10.1029/2001JD001014, 2003.

Mihele, C. M. and Hastie, D. R.: The sensitivity of the radical amplifier to ambient water vapour, Geophys. Res. Lett., 25, 19111913, 1998.

Mihele, C. M. and Hastie, D. R.: Radical chemistry at a forested continental site: Results from the PROPHET 1997 campaign, J. Geophys. Res.-Atmos., 108, 4450, doi:10.1029/2002JD002888, 2003.

Mihele, C. M., Mozurkewich, M., and Hastie, D. R.: Radical loss in a chain reaction of $\mathrm{CO}$ and NO in the presence of water: Implications for the radical amplifier and atmospheric chemistry, Int. J. Chem. Kinet., 31, 145-152, 1999.

Monks, P. S.: Gas-phase radical chemistry in the troposphere, Chem. Soc. Rev., 34, 376-395, 2005.

Monks, P. S., Carpenter, L. J., Penkett, S. A., Ayers, G. P., Gillett, R. W., Galbally, I. E., and Meyer, C. P.: Fundamental ozone photochemistry in the remote marine boundary layer: The SOAPEX experiment, measurement and theory, Atmos. Environ., 32, 3647-3664, 1998.

Morita, A., Kanaya, Y., and Francisco, J. S.: Uptake of the $\mathrm{HO}_{2}$ radical by water: molecular dynamics calculations and their implications for atmospheric modeling, J. Geophys. Res.-Atmos., 109, D09201, doi:10.1029/2003JD004240, 2004.

Neftel, A., Spirig, C., Prévôt, A. S. H., Furger, M., Stutz, J., Vogel, B., and Hjorth, J.: Sensitivity of photooxidant production in the Milan Basin: an overview of results from a EUROTRAC-2 Limitation of Oxidant Production field experiment, J. Geophys. Res., 107, 8188, doi:10.1029/2001JD001263, 2002. 
Olson, J. R., Crawford, J. H., Chen, G., Fried, A., Evans, M. J., Jordan, C. E., Sandholm, S. T., Davis, D. D., Anderson, B. E., Avery, M. A., Barrick, J. D., Blake, D. R., Brune, W. H., Eisele, F. L., Flocke, F., Harder, H., Jacob, D. J., Kondo, Y., Lefer, B. L., Martinez, M., Mauldin, R. L., Sachse, G. W., Shetter, R. E., Singh, H. B., Talbot, R. W., and Tan, D.: Testing fast photochemical theory during TRACE-P based on measurements of $\mathrm{OH}, \mathrm{HO}_{2}$, and $\mathrm{CH}_{2} \mathrm{O}$, J. Geophys. Res.-Atmos., 109, D15S10, doi:10.1029/2003JD004278, 2004.

Prévôt, A. S. H., Staehelin, J., Kok, G. L., Schillawski, R. D., Neininger, B., Staffelbach, T., Neftel, A., Wernli, H., and Dommen, J.: The Milan photooxidant plume, J. Geophys. Res., 102, 23375-23388, 1997.

Reeves, C. E. and Penkett, S. A.: Measurements of peroxides and what they tell us, Chem. Rev., 103, 5199-5218, 2003.

Reimann, S., Schaub, D., Stemmler, K., Folini, D., Hill, M., Hofer, P., Buchmann, B., Simmonds, P. G., Greally, B. R., and O'Doherty, S.: Halogenated greenhouse gases at the Swiss high Alpine site of Jungfraujoch (3580 m a.s.1.): Continuous measurements and their use for regional European source allocation, J. Geophys. Res., 109, D05307, doi:10.1029/2003JD003923, 2004.

Ren, X. R., Olson, J. R., Crawford, J. H., Brune, W. H., Mao, J. Q., Long, R. B., Chen, Z., Chen, G., Avery, M. A., Sachse, G. W., Barrick, J. D., Diskin, G. S., Huey, L. G., Fried, A., Cohen, R. C., Heikes, B., Wennberg, P. O., Singh, H. B., Blake, D. R., and Shetter, R. E.: $\mathrm{HO}_{\mathrm{x}}$ chemistry during INTEX-A 2004: Observation, model calculation, and comparison with previous studies, J. Geophys. Res., 113, D05310, doi:10.1029/2007JD009166, 2008.

Saiz-Lopez, A., Saunders, R. W., Joseph, D. M., Ashworth, S. H., and Plane, J. M. C.: Absolute absorption cross-section and photolysis rate of $\mathrm{I}_{2}$, Atmos. Chem. Phys., 4, 1443-1450, 2004, http://www.atmos-chem-phys.net/4/1443/2004/.

Salisbury, G., Rickard, A. R., Monks, P. S., Allan, B. J., Bauguitte, S., Penkett, S. A., Carslaw, N., Lewis, A. C., Creasey, D. J., Heard, D. E., Jacobs, P. J., and Lee, J. D.: Production of peroxy radicals at night via reactions of ozone and the nitrate radical in the marine boundary layer, J. Geophys. Res.-Atmos., 106, 12669-12687, 2001.

Salisbury, G., Monks, P. S., Bauguitte, S., Bandy, B. J., and Penkett, S. A.: A seasonal comparison of the ozone photochemistry in clean and polluted air masses at Mace Head, Ireland, J. Atmos. Chem., 41, 163-187, 2002.

Schmidt, R. W. H., Slemr, F., and Schurath, U.: Airborne peroxyacetyl nitrate (PAN) measurements and peroxypropionyl nitrate (PPN) measurements during TRACT 1992, Atmos. Environ., 32, 1203-1227, 1998.

Silibello, C., Calori, G., Brusasca, G., Catenacci, G., and Finzi, G.: Application of a photochemical grid model to Milan metropolitan area, Atmos. Environ., 32, 2025-2038, 1998.

Simmonds, P. G., O’Doherty, S., Nickless, G., Sturrock, G. A., Swaby, R., Knight, P., Ricketts, J., Woffendin, G., and Smith, R.: Automated gas chromatograph/mass spectrometer for routine atmospheric field measurements of the CFC replacement compounds, the hydrofluorocarbons and hydrochlorofluorocarbons, Anal. Chem., 67, 717-723, 1995.

Smith, S. C., Lee, J. D., Bloss, W. J., Johnson, G. P., Ingham, T., and Heard, D. E.: Concentrations of $\mathrm{OH}$ and $\mathrm{HO}_{2}$ radicals during NAMBLEX: measurements and steady state analysis, Atmos. Chem. Phys., 6, 1435-1453, 2006, http://www.atmos-chem-phys.net/6/1435/2006/.

Sommariva, R., Haggerstone, A.-L., Carpenter, L. J., Carslaw, N., Creasey, D. J., Heard, D. E., Lee, J. D., Lewis, A. C., Pilling, M. J., and Zádor, J.: $\mathrm{OH}$ and $\mathrm{HO}_{2}$ chemistry in clean marine air during SOAPEX-2, Atmos. Chem. Phys., 4, 839-856, 2004, http://www.atmos-chem-phys.net/4/839/2004/.

Sommariva, R., Bloss, W. J., Brough, N., Carslaw, N., Flynn, M., Haggerstone, A.-L., Heard, D. E., Hopkins, J. R., Lee, J. D., Lewis, A. C., McFiggans, G., Monks, P. S., Penkett, S. A., Pilling, M. J., Plane, J. M. C., Read, K. A., Saiz-Lopez, A., Rickard, A. R., and Williams, P. I.: $\mathrm{OH}$ and $\mathrm{HO}_{2}$ chemistry during NAMBLEX: roles of oxygenates, halogen oxides and heterogeneous uptake, Atmos. Chem. Phys., 6, 1135-1153, 2006, http://www.atmos-chem-phys.net/6/1135/2006/.

Talukdar, R. K., Burkholder, J. B., Schmoltner, A.-M., Roberts, J. M., Wilson, R. W., and Ravishankara, A. R.: Investigation of the loss processes for peroxyacetyl nitrate in the atmosphere: UV photolysis and reaction with OH, J. Geophys. Res., 100, $14163-$ 14174, 1995.

Thielmann, A., Prevot, A. S. H., and Staehelin, J.: Sensitivity of ozone production derived from field measurements in the Italian Po basin, J. Geophys. Res.-Atmos., 107, 8194, doi:10.1029/2000JD000119, 2002.

Thornton, J. and Abbatt, J. P. D.: Measurements of $\mathrm{HO}_{2}$ uptake to aqueous aerosol: mass accommodation coefficients and net reactive loss, J. Geophys. Res.-Atmos., 110, 8194, doi:10.1029/2000JD000119, 2005.

Troe, J.: Are primary quantum yields of $\mathrm{NO}_{2}$ photolysis at $\lambda<=398 \mathrm{~nm}$ smaller than unity?, Z. Phys. Chem., 214, 573-581, 2000.

Walker, S. J., Evans, M. J., Jackson, A. V., Steinbacher, M., Zellweger, C., and McQuaid, J. B.: Processes controlling the concentration of hydroperoxides at Jungfraujoch Observatory, Switzerland, Atmos. Chem. Phys., 6, 5525-5536, 2006, http://www.atmos-chem-phys.net/6/5525/2006/.

Wood, E.: Interactive comment on "Measurements of $\mathrm{OH}$ and $\mathrm{HO}_{2}$ concentrations during the MCMA-2006 field campaign - Part 1: Deployment of the Indiana University laser-induced fluorescence instrument" by S. Dusanter et al., Atmos. Chem. Phys. Discuss., 8, S5350-S5352, 2008, www.atmos-chem-phys-discuss.net/8/S5350/2008/.

Yokelson, R. J., Burkholder, J. B., Fox, R. W., Talukdar, R. K., and Ravishankara, A. R.: Temperature-dependence of the $\mathrm{NO}_{3}$ absorption spectrum, J. Phys. Chem., 98, 13144-13150, 1994.

Zanis, P., Monks, P. S., Schuepbach, E., Carpenter, L. J., Green, T. J., Mills, G. P., Bauguitte, S., and Penkett, S. A.: In situ ozone production under free tropospheric conditions during FREETEX '98 in the Swiss Alps, J. Geophys. Res.-Atmos., 105, 24223 24234, 2000a.

Zanis, P., Monks, P. S., Schuepbach, E., and Penkett, S. A.: The role of In Situ Photochemistry in the Control of Ozone during Spring at the Jungfraujoch (3,580 m asl) - Comparison of Model Results with Measurements, J. Atmos. Chem., 37, 1-27, 2000 b.

Zanis, P., Monks, P. S., Schuepbach, E., and Penkett, S. A.: On the relationship of $\mathrm{HO}_{2}+\mathrm{RO}_{2}$ with $\mathrm{j}\left(\mathrm{O}^{1} \mathrm{D}\right)$ during the Free Tropospheric Experiment (FREETEX '96) at the Jungfraujoch Observatory ( $3580 \mathrm{~m}$ above sea level) in the Swiss Alps, J. Geophys. Res.-Atmos., 104, 26913-26925, 1999. 
A. E. Parker et al.: Peroxy radicals in the summer free troposphere

Zanis, P., Monks, P. S., Green, T. J., Schuepbach, E., Carpenter, L. J., Mills, G. P., Rickard, A. R., Brough, N., and Penkett, S. A.: Seasonal variation of peroxy radicals in the lower free troposphere based on observations from the FREE Tropospheric EXperiments in the Swiss Alps, Geophys. Res. Lett., 30, 1497, doi:10.1029/2003GL017122, 2003.

Zanis, P., Ganser, A., Zellweger, C., Henne, S., Steinbacher, M., and Staehelin, J.: Seasonal variability of measured ozone production efficiencies in the lower free troposphere of Central Europe, Atmos. Chem. Phys., 7, 223-236, 2007,

http://www.atmos-chem-phys.net/7/223/2007/.
Zellweger, C., Ammann, M., Buchmann, B., Hofer, P., Lugauer, M., Ruttimann, R., Streit, N., Weingartner, E., and Baltensperger, U.: Summertime $\mathrm{NO}_{\mathrm{y}}$ speciation at the Jungfraujoch, $3580 \mathrm{~m}$ above sea level, Switzerland, J. Geophys. Res., 105, 6655-6667, 2000. 